\title{
Endothelial Progenitor Cells Dysfunctions and Cardiometabolic Disorders: From Mechanisms to Therapeutic Approaches
}

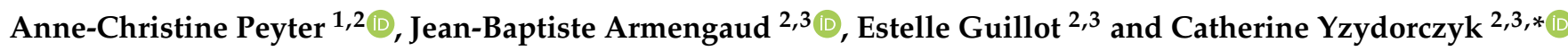 \\ 1 Neonatal Research Laboratory, Department Woman-Mother-Child, Clinic of Neonatology, \\ Lausanne University Hospital, 1011 Lausanne, Switzerland; Anne-Christine.Peyter@chuv.ch \\ 2 Faculty of Biology and Medicine, University of Lausanne, 1011 Lausanne, Switzerland; \\ jean-baptiste.armengaud@chuv.ch (J.-B.A.); estelle.guillot@unil.ch (E.G.) \\ 3 Division of Pediatrics, DOHaD Laboratory, Department Woman-Mother-Child, \\ Lausanne University Hospital, 1011 Lausanne, Switzerland \\ * Correspondence: catherine.yzydorczyk@chuv.ch; Tel.: +41-(0)2-1314-3219
}

Citation: Peyter, A.-C.; Armengaud, J.-B.; Guillot, E.; Yzydorczyk, C. Endothelial Progenitor Cells

Dysfunctions and Cardiometabolic Disorders: From Mechanisms to Therapeutic Approaches. Int. J. Mol. Sci. 2021, 22, 6667. https://doi.org/ $10.3390 /$ ijms 22136667

Academic Editor: Christopher L. Gentile

Received: 6 May 2021

Accepted: 17 June 2021

Published: 22 June 2021

Publisher's Note: MDPI stays neutral with regard to jurisdictional claims in published maps and institutional affiliations.

Copyright: () 2021 by the authors. Licensee MDPI, Basel, Switzerland. This article is an open access article distributed under the terms and conditions of the Creative Commons Attribution (CC BY) license (https:// creativecommons.org/licenses/by/ $4.0 /)$.

\begin{abstract}
Metabolic syndrome (MetS) is a cluster of several disorders, such as hypertension, central obesity, dyslipidemia, hyperglycemia, insulin resistance and non-alcoholic fatty liver disease. Despite health policies based on the promotion of physical exercise, the reduction of calorie intake and the consumption of healthy food, there is still a global rise in the incidence and prevalence of MetS in the world. This phenomenon can partly be explained by the fact that adverse events in the perinatal period can increase the susceptibility to develop cardiometabolic diseases in adulthood. Individuals born after intrauterine growth restriction (IUGR) are particularly at risk of developing cardiovascular diseases (CVD) and metabolic disorders later in life. It has been shown that alterations in the structural and functional integrity of the endothelium can lead to the development of cardiometabolic diseases. The endothelial progenitor cells (EPCs) are circulating components of the endothelium playing a major role in vascular homeostasis. An association has been found between the maintenance of endothelial structure and function by EPCs and their ability to differentiate and repair damaged endothelial tissue. In this narrative review, we explore the alterations of EPCs observed in individuals with cardiometabolic disorders, describe some mechanisms related to such dysfunction and propose some therapeutical approaches to reverse the EPCs dysfunction.
\end{abstract}

Keywords: developmental programming; intrauterine growth restriction; metabolic syndrome; endothelial progenitor cells; oxidative stress; cellular senescence

\section{Components of Metabolic Syndrome}

The incidence and prevalence of metabolic syndrome (MetS) are increasing worldwide and MetS is becoming a global health problem. MetS affects $20-30 \%$ of the population in developed countries [1]. The major components of the MetS cluster are obesity, in particular abdominal body fat accumulation, impaired glucose metabolism, dyslipidemia and arterial hypertension [2,3]. Additionally, non-alcoholic fatty liver disease (NAFLD), which is defined as excess fat ( $>5 \%$ weight or volume) deposition in the liver in the absence of excessive alcohol intake, has been identified as a hepatic manifestation of MetS [4]. NAFLD has emerged as the most common cause of liver disease, and it is associated with substantial morbidity and mortality in Western countries. Moreover, MetS has been identified as an epidemiologic tool related to cardiovascular disease (CVD) risk. In fact, each component of the MetS represents an independent risk factor for the development of CVD [5-7].

\section{Metabolic Syndrome and Endothelial Dysfunction}

The endothelium is a thin monocellular layer that covers the inner surface of blood vessels, separating the circulating blood from the interstitial fluid [8], and plays an essen- 
tial role in the maintenance of vascular homeostasis [9]. Under physiological conditions, the endothelium synthesizes paracrine factors, such as nitric oxide (NO), prostacyclin, endothelium-derived hyperpolarizing factor and natriuretic peptide type-C. These factors regulate the balance between vasodilation and vasoconstriction, inhibit and improve the proliferation and migration of smooth muscle cells, prevent and stimulate the adhesion and aggregation of platelets, and regulate thrombogenesis and fibrinolysis [10-12]. NO is the major contributor of these endothelial functions. NO is a gaseous molecule generated during the conversion of L-arginine to L-citrulline via the action of the endothelial nitric oxide synthase (eNOS), which requires the presence of tetrahydrobiopterin $\left(\mathrm{BH}_{4}\right)$ as cofactor [13]. Endothelial function can be explored notably by infusion of acetylcholine, which stimulates endothelial muscarinic receptors, leading to an increase in cytosolic $\mathrm{Ca}^{2+}$ and thus to the activation of eNOS to metabolize L-arginine into L-citrulline and NO [14]. Measurement of flow-mediated vasodilation (FMD) by ultrasound allows a noninvasive assessment of endothelial function in patients [15]. Given the large range of the vasoprotective effects of NO, the term "endothelial dysfunction" generally refers to reduced NO bioavailability, notably due to decreased eNOS expression or activity, resulting in enhanced vasoconstrictor responses and thus impaired endothelium-dependent vasodilation [16].

Therefore, an alteration in the structural and functional integrity of the endothelium can lead to the development of cardiometabolic disorders. All components of MetS can individually be associated with impaired endothelial function. Several studies have shown that hypertension $[17,18]$ and abdominal obesity $[19-21]$ are associated with endothelial dysfunction. In patients with type-2 diabetes, elevated glucose levels lead to glycosylation of vascular endothelium, resulting in changes in blood vessels such as narrowing and sprouting of neovasculature that is friable and at risk of rupture [22-24]. It has been shown that patients with type-2 diabetes have a 2- to 4-fold increased risk of developing CVD compared with non-diabetic individuals [25], related to endothelial dysfunction, as a consequence of inflammation, increased reactive oxygen species (ROS) production and deletion of eNOS [26-28]. Patients with NAFLD and non-alcoholic steatohepatitis also display an impaired endothelial function characterized by decreased FMD [29-31].

\section{Endothelial Progenitor Cells}

The endothelial progenitor cells (EPCs) are circulating components of the endothelium. They are mobilized and migrate in the circulation from the bone marrow, differentiate into mature endothelial cells, and synthesize and release a wide range of active molecules and growth factors modulating vasculogenesis and improving vascular homeostasis $[32,33]$. A close association has been identified between the maintenance of endothelial structure and function by EPCs and their ability to differentiate and repair damaged endothelial tissue [34]. EPCs are most frequently isolated from cord blood [35,36] or peripheral blood [35,37], but can also be isolated from pulmonary artery endothelium [38,39] or placenta [40], or can be derived from induced pluripotent stem cells [41]. EPCs can be distinguished according to their phenotype and functional properties in vivo [42]. Early EPCs have a hematopoietic origin and promote angiogenesis through paracrine mechanisms but cannot give rise to mature endothelial cells [42-45]. In contrast, endothelial colony forming cells (ECFCs) or late outgrowth EPCs [42] have clonal potential and the capabilities to yield mature endothelial cells and to promote vascular formation in vitro and in vivo. In particular, these cells are capable of proliferation, autorenewal, migration, differentiation, vascular growth and neovascularization. It has been demonstrated that ECFCs can be characterized by the assessment of surface markers, such as CD34 and vascular endothelial growth factor receptor-2 (VEGFR-2, also named KDR) [46,47], but the absence of CD45. Importantly, the CD34 ${ }^{+} \mathrm{KDR}^{+}$combination is the only putative ECFCs phenotype that has been repeatedly and convincingly demonstrated to be an independent predictor of cardiovascular outcomes $[48,49]$. EPCs have not only a potential therapeutic impact on endothelial dysfunction in both clinical [50] and experimental [51] studies, but also the circulating levels of EPCs can be used as a clinical marker of disease progression [52]. EPCs 
dysfunction has been characterized by decreased number and/or impaired function of circulating precursors [53]. The number of circulating EPCs was found to be negatively correlated with cardiovascular risk factors and vascular function and to predict CVD independently of both conventional and non-traditional cardiovascular risk factors [54-56].

\section{Endothelial Progenitor Cells Dysfunction in Cardiometabolic Disorders \\ 4.1. Endothelial Progenitor Cells Dysfunction in Type-2 Diabetes}

In patients with type-2 diabetes, a decrease in the number of EPCs has been reported, and the number of EPCs was lower as more numerous were the complications [57]. Notably a reduction in $\mathrm{CD} 34^{+}$EPCs has been mentioned in early stages of type-2 diabetes, which persists thereafter and worsens in patients with diabetes complications [58]. EPCs isolated from patients with type-2 diabetes have demonstrated impaired functions such as alterations of proliferation, migration, chemokinesis, angiogenesis and NO bioavailability [59] compared to nondiabetic patients [60-62], as observed also in EPCs from animal models of diabetes [63-66].

In addition, it is well known that endothelial dysfunction induced by hyperglycemia leads to micro- and macro-angiopathies complications [67]. A reduced number of EPCs in type-2 diabetes has been associated to increased brachial-ankle pulse wave velocity related to arterial stiffness [68] and is correlated to the prevalence of peripheral vascular disease [69-71] and with the degree of atherosclerosis [72]. Additionally, high glucose might impair EPCs by modifying NO-related mechanisms [73].

\subsection{Endothelial Progenitor Cells Dysfunction in Hypertension and Cardiovascular Diseases}

EPCs seem to play a protective role against the development of CVD [74]. In fact, several CVD have been associated with altered EPCs number and functions. In prehypertensive patients, an impaired formation of EPCs colonies has been mentioned [75]. Patients with hypertension and vascular lesions displayed a reduced number of circulating $\mathrm{CD}_{4} 4^{+}$cells [76]. In contrast, Skrzypkowska et al. observed that patients with essential hypertension had increased proportions of CD34 ${ }^{+}$EPCs [77], which may be a compensatory mechanism. Marketou et al. did not find any significant difference in the number of circulating $\mathrm{CD}_{3}{ }^{+}$cells between hypertensive and normotensive individuals, but found a correlation between the number of circulating $\mathrm{CD} 34^{+}$cells and pulse wave velocity in hypertensive patients, suggesting a role for EPCs in the pathophysiology of arterial stiffness and arterial remodeling [78]. Hypertension is a risk factor for the incidence of other CVD such as stroke, coronary artery disease, sudden death, heart failure and peripheral arterial disease $[79,80]$. Hill et al. found a correlation between the number of circulating EPCs and the patient's combined Framingham risk factor score, which includes six coronary risk factors, such as age, gender, total cholesterol, high density lipoprotein cholesterol, smoking habits and systolic blood pressure value [81,82]. Vasa et al., showed an impaired migration function of EPCs in patients with coronary artery disease [83]. In hypertensive patients with left ventricular hypertrophy, the circulating levels and adhesive function of EPCs were lowered compared to non-hypertensive patients [84]. A significant reduction of EPCs number and proliferation rate has been also observed in patients with peripheral artery disease [85] alone and combined with diabetes $[70,86]$.

\subsection{Endothelial Progenitor Cells Dysfunction in Obesity}

In obese patients, a decrease in EPCs number associated with significantly impaired clonogenic properties and an altered capacity to incorporate into tubule structures has been observed [87]; the decrease in EPCs number was reversed by weight loss [88,89]. In a C57BL/6J mice model of obesity induced by high fat diet, the number of EPCs from adipose tissue was significantly lower, as well as the circulating level of EPCs in response to ischemia, compared to control mice. The colony-forming capacity of peripheral blood-derived EPCs and the angiogenic capacity in response to ischemic stimulation were markedly altered in the obese mice compared to controls [90]. In addition, an impaired 
recovery of damaged endothelium, reduced EPCs angiogenesis ability and left ventricular ejection fraction, and an increased left ventricular remodeling have been observed in the obese compared to control mice [91].

\subsection{Endothelial Progenitor Cells Dysfunction and Dyslipidemia}

Dyslipidemia is characterized by increased triglyceride concentrations, decreased plasma high-density lipoprotein (HDL)-cholesterol levels and an increased proportion of small, dense low-density lipoprotein (LDL) particles, despite normal LDL-cholesterol. Hypercholesterolemia has been associated with reduced EPCs availability [92,93]. In vitro exposure of EPCs to oxidized-LDL decreased their number and impaired their adhesive, migratory and tube-formation capacities in a dose-dependent manner [94].

\subsection{Endothelial Progenitor Cells Dysfunction and NAFLD}

NAFLD is currently well recognized as a hepatic manifestation of MetS [95] and has been associated with obesity, insulin resistance, systemic inflammation and advanced atherosclerosis [96,97]. In addition, NAFLD has been related to endothelial dysfunction [98]. Patients with NAFLD have decreased number and function of circulating EPCs associated with features of MetS [99]. However, it has been shown that the number of EPCs was higher in patients with NAFLD and MetS in comparison to those without these conditions, and that the EPCs number was directly proportional to the degree of liver steatosis. The increase in EPCs number could be considered as a compensatory mechanism against endothelial injury [100].

\section{Mechanisms Potentially Associated with Impaired Functionality of Endothelial Progenitor Cells}

Several mechanisms have been identified to impair EPCs functionality (Figure 1).

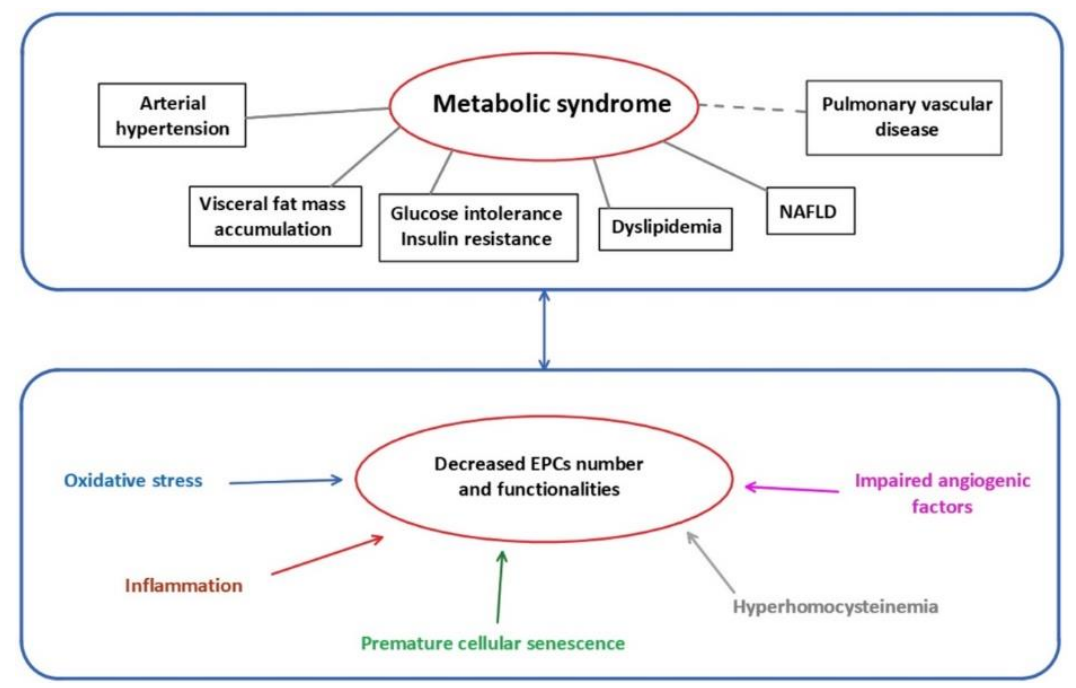

Figure 1. Metabolic syndrome and mechanisms related to EPCs dysfunctions. EPCs: endothelial progenitor cells; NAFLD: non-alcoholic fatty liver disease.

\subsection{Oxidative Stress}

ROS are chemically reactive molecules formed during the metabolism of molecular oxygen. ROS are necessary in several biochemical processes such as intracellular signaling, cell differentiation, growth arrest, apoptosis, immunity and defense against microorganisms. The natural antioxidant system consists of a series of antioxidant enzymes, such as superoxide dismutases (SOD), catalase and glutathione peroxidase, and of endogenous antioxidant compounds. Oxidative stress occurs when the amount of ROS exceeds the antioxidant capacity. Excessive ROS production can interact with cellular macromolecules and then enhance the process of lipid peroxidation, cause DNA damage and/or induce 
protein and nucleic acid modifications [101], leading to decreased biological activity, dysregulated metabolism and alterations in cell signaling. In addition, oxidative stress can affect NO synthesis and bioavailability. Superoxide anion is known to interact with NO, leading to the formation of peroxynitrite, a highly reactive and toxic species able to modify macromolecules, such as lipids, proteins and DNA. Moreover, it has been suggested that increased oxidation of $\mathrm{BH}_{4}$ to 7,8 -dihydropteridine $\left(\mathrm{BH}_{2}\right)$ results in a reduced availability of this cofactor for eNOS [102], which impairs its activity and therefore NO production. Additionally, oxidative stress leads to increased endothelial-derived constricting factors such as endothelin-1 (ET-1), angiotensin II, thromboxane A2 and prostaglandin $\mathrm{H} 2$, thus enhancing vasoconstriction and contributing to endothelial dysfunction [103]. In addition, asymmetric dimethylarginine (ADMA), an endogenous competitive inhibitor of eNOS, inhibits the formation of $\mathrm{NO}$ and can lead, via eNOS uncoupling, to increased superoxide radical generation. Oxidative stress has been associated with decreased EPCs levels associated with reduced capability of mobilizing, migrating and incorporating into existing vasculature [62,104-106].

The expression of antioxidant enzymes, such as SOD, catalase and glutathione peroxidase, in EPCs is higher compared to endothelial cells [107] in the purpose to improve EPCs survival within the oxygen-poor environment of the bone marrow, as well as to support the ability of EPCs to engraft within ischemic tissues during the vasculogenesis process [107-110]. Dyslipidemia can lead to oxidative stress and so to EPCs dysfunction. In fact, oxidized-LDL, as oxygen donors, are responsible for inciting and perpetuating oxidative stress through a spiral of redox-based reactions, which impairs the vasculogenic function of EPCs [111]. In contrast, HDL, which have antioxidant and anti-inflammatory properties, have a positive impact on EPCs physiology [112].

Mitochondria play an important role in energy homeostasis by the production of ATP via oxidative phosphorylation and the oxidation of metabolites via the Krebs's cycle and the beta-oxidation of fatty acids. Mitochondrial dysfunction is the major source of ROS production $(0.2 \%$ to $2 \%$ of total oxygen taken up by cells), mainly at complex I (NADH CoQ reductase) and complex III (bc1 complex). Under normal conditions, the overproduction of ROS in mitochondria is restricted via enzymatic and non-enzymatic defense systems to protect cellular organelles from oxidative damage. However, when antioxidant defenses are overwhelmed, there is an overproduction of ROS, which then leads to oxidative damage to proteins, DNA and lipids in mitochondria $[113,114]$. An altered mitochondrial activity in EPCs has been observed in patients with cerebrovascular disorder [115] and type-2 diabetes [116].

\subsection{Cellular Senescence}

Cellular senescence is a biological phenomenon triggered by potentially harmful stimuli, during which the cell interrupts the division process, entering a state of cell cycle arrest and becoming quiescent. Senescence is a protective mechanism affecting the majority of the cells within an organism [117]. At the phenotypic level, senescent cells acquire a characteristic flattened and enlarged morphology with accumulation of lipofuscin, which is a marker of highly oxidized, insoluble proteins [118]. Cellular senescence is also characterized by a decline in the DNA replication in the cells, until they cease to proliferate, associated with molecular changes in elements related to the cell cycle (pRb, p21 ${ }^{\mathrm{WAF}}, \mathrm{p} 16^{\mathrm{INK} 4 \mathrm{a}}$ and p53) [119]. Moreover, senescent cells undergo chromatin and secretome changes, genomic and epigenomic damage, unbalanced mitogenic signals and tumor-suppressor activation [120]. In addition to these common characteristics, replicative senescence can be identified by a decline in telomere length with each cell cycle [121]. Replicative senescence is an irreversible phenomenon, in contrast to stress-induced premature senescence (SIPS). SIPS is initiated in young cells via different mechanisms, such as oxidative stress, and has been associated with the over-expression of $\mathrm{p} 16^{\mathrm{INK} 4 \mathrm{a}}$ and the decreased functionality of the anti-aging protein sirtuin-1 [122]. Moreover, senescent cells can exhibit an upregulation and secretion of growth factors, such as proinflammatory cytokines (IL-6 and IL-1), 
chemokines (IL-8, chemokine ligands family members), macrophage inflammatory protein and insulin-like growth factor, and also a release of extracellular matrix-degrading proteins (MMP family, serine proteases and fibronectin); the overall effect of these phenomena leads to the senescence-associated secretory phenotype (SASP) [123]. It is important to note that most senescent cells are resistant to some apoptosis signals, therefore they become senescent [119].

EPCs isolated from cord blood of diabetic mothers displayed in vitro premature senescence and impaired proliferation and in vivo reduced vasculogenic potential compared to uncomplicated pregnancies [124]. Oxidative stress and senescence are hallmarks often associated. An increased ROS production as well as oxidized-LDL have been associated with cellular senescence of EPCs $[109,125]$, decreasing their number and impairing their function. Moreover, an association has been observed between oxidative DNA damage, decreased telomerase activity and decreased telomere length in EPCs isolated from patients with MetS and coronary artery disease [126].

\subsection{Impaired Angiogenic Function}

Angiogenesis is important to maintain the integrity of tissue perfusion, which is crucial for physiologic organ function. EPCs, and more particularly ECFCs, play a major role in the angiogenic process. In fact, it has been shown that ECFCs contribute not only to maintain microvasculature but also to stimulate postnatal angiogenesis [127-129].

$\mathrm{NO}$ is necessary for angiogenesis to occur [130]. NO is involved in the mobilization of EPCs and improves their migratory and proliferative activities [131], notably by the regulation of their angiogenic activity [132,133]. NO-mediated signaling pathways are essential for EPCs mobilization from the bone marrow [134-136]. NO regulates migration of EPCs into ischemic sites [61,136,137] and improves their survival [138]. A link between eNOS expression/functionality and EPCs function has been described [139]. In diabetic EPCs, eNOS activity is decreased, probably due to eNOS uncoupling, leading to reduced NO production and thus to decreased migratory capability, which is restored by exogenous NO administration $[136,140,141]$. The NO-donor sodium nitroprusside improved migration and tube formation, which was impaired by hyperglycemia [142]. ADMA levels are increased in diabetes [143] and it has been shown that ADMA decreased EPCs proliferation and differentiation, in a concentration-dependent manner [106].

$\mathrm{NO}$ can interact with angiogenic factors. Vascular endothelial growth factor (VEGF) plays an important role in EPCs differentiation and vascular repair [144,145]. A reciprocal relation between NO and VEGF has been demonstrated. The synthesis of VEGF can be induced by NO [146,147], and VEGF increases NO production by eNOS, promoting angiogenesis [148]. In patients with coronary heart disease, a reduced NO bioavailability has been observed, associated with altered VEGF expression and subsequently impaired EPCs functionality $[149,150]$. Moreover, a decreased secretion of NO and VEGF induced by hyperglycemia condition or advanced glycation end-products decreased activity of SOD, and so impaired EPCs function, such as migration and tube formation [151].

\subsection{Inflammation-Induced EPCs Dysfunction}

EPCs function and maturation are extremely sensitive to inflammation mediators. Autoimmune diseases like systemic lupus erythematosus (SLE) or rheumatoid arthritis as well as metabolic anomalies like type-2 diabetes mellitus demonstrate endothelial dysfunction related to chronic inflammation and later to CVD [152]. Patients with SLE displayed a chronic inflammatory state and a higher risk of MetS associated with a decreased level of circulating EPCs [153]. Interestingly, adipokines are critical mediators of inflammation and insulin resistance in SLE-associated MetS [154].

The level of type-I interferon impacts the EPCs number and function [155], especially in reducing their ability to repair vascular damage $[156,157]$. In a murine model, a type-1 interferon receptor knockout led to increased EPCs number and function, with improved neoangiogenesis and cell differentiation [158]. The blockade of IL-18 also enhanced dif- 
ferentiation of EPCs [159]. Increased expression of tumor necrosis factor $\alpha$ (TNF $\alpha)$ had detrimental effects on EPCs function as impaired proliferation, migration and tube formation [160]. Stromal cell-derived factor-1 (SDF-1) is a cytokine stimulating the recruitment of proinflammatory cells that contributes to EPCs mobilization [161]. In patients with type-2 diabetes, hyperglycemia reduces the level of VEGF and SDF-1 secretion from endothelial cells via the hypoxia-inducible factor/hypoxia-response element pathway and dipeptidyl peptidase-4 activity [162], therefore decreasing the mobilization of EPCs from bone marrow to circulation $[163,164]$ and impairing the regulation of growth, migration and survival of EPCs [165].

\subsection{Epigenetic Regulation \\ 5.5.1. MicroRNAs}

MicroRNAs (miRNAs) have been identified to play important roles in the posttranscriptional regulation of gene expression influencing several cellular processes which contribute to disease $[166,167]$. Several miRNAs have been identified to regulate endothelial cell functions, such as cell proliferation, senescence, migration, differentiation and vascular tubule formation [168-170]. Therefore, an alteration of miRNAs expression can contribute to EPCs dysfunctions. It has been shown that miR-126 expression is necessary to downregulate Spred-1 to activate Ras/ERK/VEGF and PI3K/AKT/eNOS signaling pathways, improving EPCs proliferation and migration [171]. MiR-130a expression is involved in the proliferation, migration and colonies formation via RUNX3/ ERK/VEGF and PI3K/AKT signaling pathways [172]. Additionally, miR-31 is involved in the expression of several proteins implicated notably in the differentiation of bone-forming stem cells into mesenchymal and fat tissues $[173,174]$. In EPCs isolated from patients with type-2 diabetes, a downregulation of miR-126 and miR-130a, but an increase in miR-31 expression have been associated with an impairment of their function [171,172,175]. In addition, miR-34a overexpression led to increased EPCs senescence, associated with decreased sirtuin- 1 functionality [176] and elevated miR-31-triggered apoptosis, which impaired EPCs functions in diabetic patients [177].

\subsubsection{DNA Methylation}

DNA methylation is the best-known epigenetic mechanism, and usually leads to repressed transcription of the involved gene. Methylation takes place on CpG islands located mainly in the promoter region of the genes. Usually, if the CpG islands in the promoter region are unmethylated, the gene is transcribed, but when a significant part of these islands is methylated, the gene can no longer be transcribed, being so silenced. DNA methylation can be altered by early environmental factors [178]. Methyl CpG binding protein 2 (MeCP2) is an important member of the methyl-CpG binding protein family. It has been shown that overexpression of MeCP2 reduced angiogenesis, via decreased protein levels of p-eNOS/eNOS and VEGF and induced senescent EPCs dysfunction through sirtuin-1 promoter hypermethylation [179].

\subsubsection{Histone Modification}

In the nucleus, DNA is packaged into chromatin as repeating units of nucleosomes, which form a "beads-on-a-string" structure that can compact into higher order structures to affect gene expression. Nucleosomes are composed of 146-bp DNA wrapped in histone octamers (composed of two H2A, H2B, H3 and $\mathrm{H} 4$ ) and are connected by a linker DNA, which can associate with histone $\mathrm{H} 1$ to form heterochromatin. Histone proteins contain a globular domain and an amino-terminal tail, with the latter being post-translationally modified. The post-translational modifications of lysine (acetylation, methylation, ubiquitination, sumoylation), arginine (methylation), as well as serine and threonine (phosphorylation) are the most described. It has been shown that the transcriptionally active H3K4me3 state leads to the activation of multiple pro-angiogenic signaling pathways (VEGFR, CXCR4, WNT, NOTCH, SHH) which improved the capacity of EPCs to form capillary-like networks 
in vitro and in vivo [180]. The concomitant inhibition of silencing histone modification (H3K27me3) and enhancement of activating histone modification (H3K4me3) improved eNOS expression in EPCs [181].

\subsection{Hyperhomocysteinemia}

Hyperhomocysteinemia is a clinical condition characterized by a high level of homocysteine in blood (above $15 \mu \mathrm{mol} / \mathrm{L}$ ) [182-184]. Homocysteine is a sulfur-containing amino acid synthesized during the metabolism of methionine. It is catabolized either by remethylation to methionine, catalyzed by methionine synthase or betaine homocysteine methyl transferase, or by transsulfuration, catalyzed by cystathionine $\beta$-synthase (CBS) and cystathionine $\gamma$-lyase (CSE), leading to cysteine, a precursor of glutathione [185-187]. CBS and CSE require vitamin B6 as co-factor. A rate-limiting CBS enzyme as well as an insufficient dietary supply of cofactors have been involved in severe cases of hyperhomocysteinemia [188-190]. Other causes have also been identified, such as smoking, renal failure and other systemic diseases [191].

Hyperhomocysteinemia is an independent risk factor for cardiovascular disorders [192]. It has been associated with endothelial dysfunction in several animal models [193-195]. Hyperhomocysteinemia has been shown to contribute to endothelial dysfunction by induction of oxidative stress. In fact, hyperhomocysteinemia increases inducible nitric oxide synthase (iNOS) synthesis and ROS production [196], associated with SOD inactivation [197,198], so generating important quantities of peroxynitrite $[196,199]$ and, therefore, contributing to nitrative stress which induces severe damage to proteins, lipids and DNA [200-202]. EPCs are particularly sensitive to oxidative stress, so hyperhomocysteinemia can contribute to EPCs dysfunction. It has been shown that homocysteine dose- and time-dependently impaired EPCs proliferative, migratory, adhesive and in vitro vasculogenesis capacities [203]. A significant decrease in circulating EPCs number and impaired functional capacity were observed in patients with hyperhomocysteinemia [204]. In mice, hyperhomocysteinemiainduced nitrative stress contributed directly to the injury of EPCs, by decreasing their survival rate, inducing apoptosis and necrosis [205]. In patients with stroke, high plasma level of homocysteine has been associated with a reduced number of EPCs colonies related to apoptosis [206,207], and administration of B vitamins (B6, B9) was able to attenuate such effects [206]. DNA methylation is an important process for gene transcription and therefore for regulation of protein expression. EPCs isolated from bone marrow in a mice model fed with a high methionine-rich diet displayed a reduced adhesion capacity and tube formation abilities associated with hyper-methylation in the CpG islands of the CBS promoter, leading to downregulated CBS expression. Such dysfunctions were reversed by administration of a DNA methylation inhibitor to mice fed with a high methionine-rich $\operatorname{diet}$ [208].

Homocysteine and hydrogen sulfide $\left(\mathrm{H}_{2} \mathrm{~S}\right)$ are interconnected. $\mathrm{H}_{2} \mathrm{~S}$ is an endogenous gasotransmitter, produced by CSE, CBS and 3-mercaptopyruvate sulfur transferase $[187,209,210]$. $\mathrm{H}_{2} \mathrm{~S}$ acts via the S-sulfhydration of cysteine residues (-SH) of target proteins to form persulfide group (-SSH), which can modify the structure and activity of various target proteins [210,211]. $\mathrm{H}_{2} \mathrm{~S}$ is emerging as an essential contributor to homeostasis of endothelial function, besides NO. It is involved in the regulation of several systems such as cardiovascular, nervous, gastrointestinal and renal systems, but also in the inflammatory and immune responses [212]. In the cardiovascular system, $\mathrm{H}_{2} \mathrm{~S}$ is produced in cardiomyocytes, vascular endothelial cells, smooth muscle cells and EPCs [213]. $\mathrm{H}_{2} \mathrm{~S}$ exerts antioxidant, anti-apoptotic, anti-inflammatory and vasoactive activities, and regulates proliferation, migration and angiogenesis, in an autocrine and paracrine manner $[209,210,214-216] . \mathrm{H}_{2} \mathrm{~S}$ induces vasorelaxation by opening of $\mathrm{K}_{\text {ATP }}$ channels in vascular smooth muscle cells and partially through a $\mathrm{K}^{+}$conductance in endothelial cells [217]. $\mathrm{H}_{2} \mathrm{~S}$ can decrease inflammation by inhibiting transcription factors such as NF-kB [218]. $\mathrm{H}_{2} \mathrm{~S}$ can reduce oxidative stress, through direct scavenging of oxygen and nitrogen species and enhancing antioxidant defense mechanisms, notably via the Keap1/Nrf2 pathway, and delays senescence [219]. In addition, $\mathrm{H}_{2} \mathrm{~S}$ can also interact with the NO/NOS 
pathway to control vascular function, thanks the inhibition of phosphodiesterases in smooth muscle cells, by PI3K/AKT-dependent phosphorylation of eNOS in Ser1177 and by stabilization of eNOS in the dimeric state [220-222]. Moreover, $\mathrm{H}_{2} \mathrm{~S}$ is a major factor to ensure EPCs functionality. In diabetic leptin receptor deficient $\mathrm{db} / \mathrm{db}$ mice, the $\mathrm{H}_{2} \mathrm{~S}$ plasma levels were significantly reduced and associated with impaired EPCs functionality such as tube formation, adhesive function and wound healing by decreasing angiogenesis process [223]. Shear stress was found to improve several EPCs functions, such as proliferation, migration, tube formation and reendothelialization [224-226], probably through enhancement of $\mathrm{H}_{2} \mathrm{~S}$ production [227]. Indeed, shear stress was able to increase $\mathrm{H}_{2} \mathrm{~S}$ production and CSE protein expression in human EPCs in a dose- and time-dependent manner, and to improve EPCs proliferation, migration and adhesion capacity [228].

As biogenesis of $\mathrm{H}_{2} \mathrm{~S}$ and homocysteine is regulated by each other and imbalance between both molecules seems implicated in several cardiovascular disorders, the $\mathrm{H}_{2} \mathrm{~S}$ / homocysteine ratio could be useful for cardiovascular risk prediction [186].

\section{Developmental Programming of Cardiometabolic Diseases}

The nutritional environment during the fetal and perinatal periods plays a major role not only in optimal offspring development, but also in adult health. In the 1980s, D. Barker observed, in a large cohort of adult men and women in Hertfordshire (UK), that a low birth weight (LBW), which is an indirect clinical marker of inappropriate intrauterine development, was inversely correlated with the risk of CVD and mortality [229]. Epidemiological studies on the Dutch Famine and on the Great Chinese Famine have reported an association between alterations in early nutrition and later development of cardiometabolic diseases $[230,231]$. These observations suggested the existence of a critical time window, from conception throughout pregnancy to early infancy, that is sensitive to long-lasting effects of environmental perturbations and could therefore potentially lead to the determination of final health outcomes by mis-programming. During this period of vulnerability, epigenetic modifications have been identified to play an important role in the regulation of the later development and long-term health outcomes.

LBW, as a consequence of intrauterine growth restriction (IUGR) or preterm birth, is associated not only with important perinatal mortality and morbidity, but also with long-term outcomes, such as cardiometabolic disorders [232]. Infants born following IUGR are at increased risk of elevated arterial blood pressure during infancy [233], adolescence [234,235], young adulthood [236] and later in life [237-239]. Among the mechanisms potentially involved in the development of arterial hypertension, alterations of the vascular system have been identified to play an important role, in addition to the long-term effects of decreased nephron endowment and hypothalamic-pituitary-adrenal axis hyperactivity [240]. Indeed, infants born following IUGR display notably impaired endothelium-dependent vasodilation and an increase in some markers related to arterial stiffness, such as increased intima media thickness and decreased arterial compliance [241-244]. Primary cultures of placental and umbilical endothelial cells derived from pregnancies complicated by IUGR showed abnormal phenotypes [245], characterized by an altered expression of proteins involved in NO-dependent vasodilation and changes in the proteome profile [246], suggesting an early programming of endothelial dysfunction.

In a rat model of IUGR induced by impaired maternal nutrition, Grandvuillemin et al. observed as early as at 5 weeks after birth, an impaired endothelium-dependent vasodilation in response to acetylcholine in the IUGR group, due to an upregulation of the arginase pathway and eNOS uncoupling, whereas no elevation in arterial blood pressure was observed at this age [247]. Thereafter, in adulthood, IUGR males displayed a higher arterial blood pressure, an increased vasoconstriction in response to angiotensin II, normalized by tempol (a radical scavenger and SOD-mimetic), an impaired endothelium-independent vasodilation in response to sodium nitroprusside in the aorta and a microvascular rarefaction as compared to control animals. These dysfunctions have been associated with increased vascular superoxide anion production mediated by NADPH oxidase and decreased cel- 
lular antioxidant glutathione levels in late gestation [248,249], so suggesting that nutrient depletion during fetal development could decrease antioxidant defenses, therefore leading to oxidative stress and vascular dysfunction.

Regarding metabolic alterations, a relationship has been mentioned between LBW and the development of type-2 diabetes in adulthood [250], obesity in 10- to 13-year-old schoolchildren [251] and the development of MetS in young adults [252]. Infants born following IUGR are also at risk to develop NAFLD later in life [253]. An association has been observed between LBW and increased levels of liver enzymes, such the aspartate aminotransferase (ASAT) and alanine aminotransferase (ALAT), measured in women aged 60-79 years, suggesting an impaired hepatic cellular function in these individuals [254].

Data have suggested that fetal life could alter the EPCs number and functionality. In fact, Meister et al. observed a 50\% decrease in $\mathrm{CD} 34^{+}$cells in preterm neonates compared to term neonates [255]. In addition, a reduced number of circulating EPCs isolated from cord blood at birth has been observed in preterm infants [256], as well as in IUGR-complicated pregnancies $[257,258]$. EPCs isolated from cord blood of newborns with LBW displayed an impaired angiogenic function related to premature senescence, mediated by reduced sirtuin-1 functionality $[122,259]$, and was associated with endothelial microparticle release due to the activation of the MKK6/p38MAPK pathways leading to the phosphorylation of Hsp27, which can contribute to the disruption of endothelial homeostasis [260]. In addition, neonatal EPCs isolated from diabetic mothers exhibited decreased proliferation and reduced vessel-forming capacity in vitro and in vivo, associated with premature senescence and oxidative DNA damage, compared with neonatal EPCs isolated from mothers with uncomplicated pregnancies [124].

Epidemiological studies and experimental models showed that impaired fetal growth induced short- and long-term adverse effects on lung structure and function [261-263]. In a rat model of IUGR induced by a maternal low-protein diet, lungs displayed a decreased alveolarization and vascularization [264]. In another rat model of IUGR induced by maternal undernutrition during pregnancy, adult exposure to chronic hypoxia induced pulmonary arterial hypertension (PAH) and pulmonary vascular remodeling correlated with molecular alterations in pulmonary vascular endothelial cells [265]. Impaired EPCs number and functional capacity were observed in patients with idiopathic PAH [266]. Circulating EPCs number was reduced in patients with $\mathrm{PAH}$, which also exhibited abnormal levels of inflammatory mediators, cGMP, NO oxidation products and ADMA [267]. Although a correlation between MetS and pulmonary disease has not yet been clearly established, insulin resistance and dysregulated glucose metabolism have been found to be associated with the development of pulmonary vascular diseases such as PAH [268].

\section{Reversibility of EPCs Dysfunction}

Several compounds and lifestyle have been identified to improve EPCs functionality (Figure 2). 


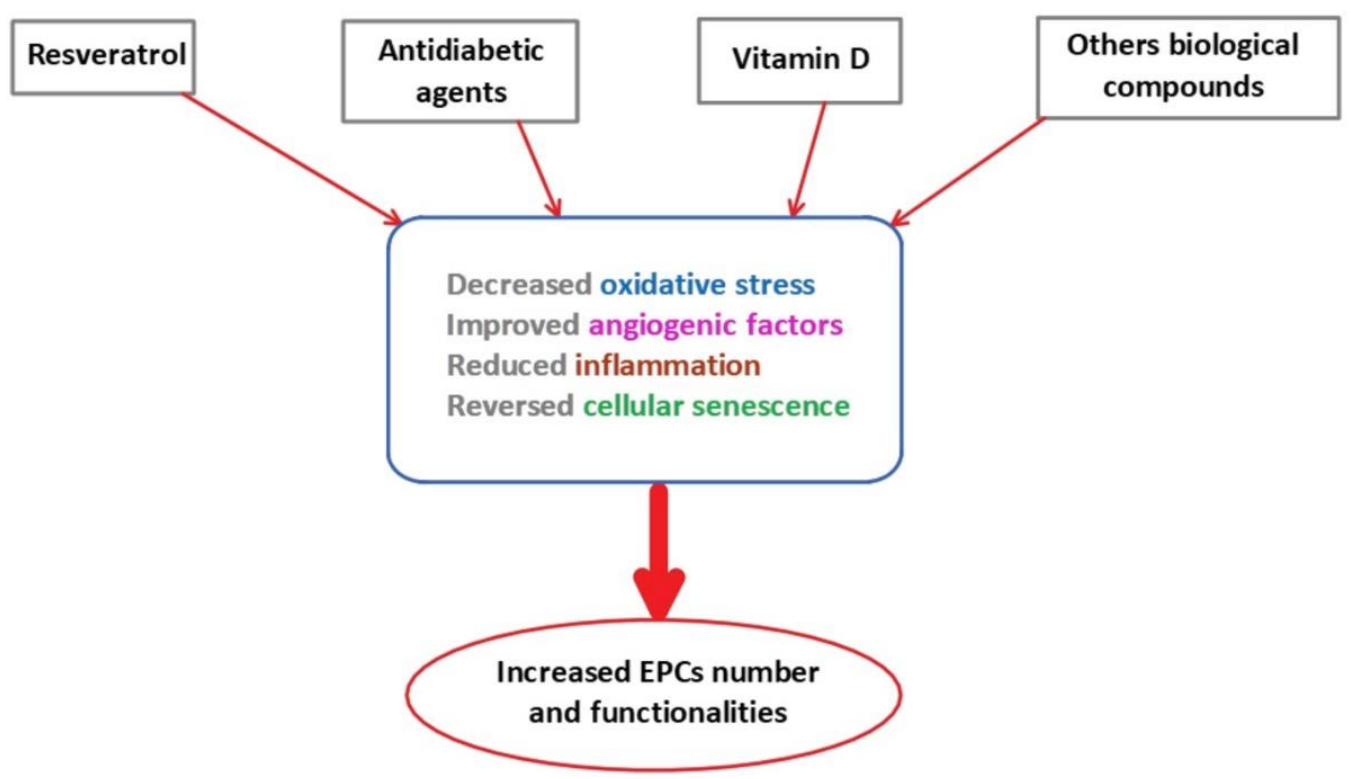

Figure 2. The effects of therapeutical agents on EPCs number and functionality. EPCs: endothelial progenitor cells.

\subsection{Resveratrol}

Epidemiological studies have shown a low prevalence of CVD in the population of Southern France, despite a diet rich in saturated fat and cholesterol [269,270]. This so-called 'French paradox' has been attributed to a moderate consumption of red wine, in which resveratrol (trans-3,5,4'-trihydroxystilbene), a natural polyphenol, has been found in significant amounts. Resveratrol was first isolated in 1939 from Veratrum grandiflorum's roots and is henceforth widely known as a phenolic compound with powerful antioxidant activity [271]. Resveratrol is present in several plants, including grape skins, grape seeds, giant knotweed, cassia seeds, passion fruit, white tea, plums and peanuts [272,273]. It has been shown that resveratrol can mimic calorie restriction and so promote good health [274]. Studies have reported that resveratrol can confer a protective effect on the cardiovascular system and metabolic disorders [275-278]. In fact, Wang et al. demonstrated that resveratrol promoted the proliferation, adhesion and migration of EPCs in a dose- and time-dependent manner and increased the expression of VEGF to further induce vasculogenesis [279,280], which was mediated by the activation of sirtuin-1 [281] and the regulation of the Synd4/AKT/eNOS pathway [282]. As a matter of fact, antioxidant properties of resveratrol are more likely attributed to its effect as regulator of the gene expression of pro-oxidative and antioxidative enzymes rather than its radical scavenging action [283]. Resveratrol also delayed the senescence of EPCs by increasing telomerase activity to maintain appropriate levels and function of EPCs [284,285], and by increasing sirtuin-1 functionality [122]. Resveratrol also prevented oxidative stress induced by diabetes in EPCs via sirtuin-1 activation [286] and modulation of the gene expression of SOD, glutathione peroxidase and NADPH oxidase subunit [287].

\subsection{Oral Antidiabetic Agents}

EPCs dysfunctions are closely related to impaired glucose metabolism and hyperglycemia. Therefore, improved hyperglycemia control could represent an interesting therapeutic target. Metformin is the main medication used in patients with type-2 diabetes. Metformin acts principally by inhibiting absorption of glucose in the gut, suppressing gluconeogenesis and glycogen synthesis, so improving the uptake and utilization of glucose, and also the sensitivity to insulin of peripheral tissues [288]. In addition, metformin exerts a positive effect on stem cells. In fact, this drug increased the number of circulating EPCs in patients with type-2 diabetes [289]. The potential effect of metformin on EPCs functionality could be due to its activation of AMP-activated protein kinase (AMPK) [290,291]. Indeed, 
it has been shown that AMPK stimulates eNOS and NO production [292], therefore improving EPCs mobilization and so their biological functions. In addition, AMPK activation by metformin can stimulate sirtuin-1 functionality [293], which was impaired by hyperglycemia, and so delay premature senescence [294]. It has been also shown that metformin improved angiogenesis of EPCs through increased VEGF-A levels and downregulated angiogenic inhibitors such as CXCL-10 and TIMP-1 [295].

Moreover, to potentially improve the positive effects of metformin on EPCs, it has been proposed to combine metformin with other oral antidiabetic compounds with antioxidant effects such as gliclazide [296-298]. It has been shown that this combination was more effective than metformin alone on the increase in the circulating EPCs level in patients with type-2 diabetes despite similar glycemic control [299]. Two other antidiabetic agents have been identified also to improve EPCs functions: the glucagon-like peptide- 1 agonist and dipeptidyl peptidase- 4 inhibitors. They act by increasing the incretin level to inhibit glucagon release and therefore improving the insulin secretion. It has been shown that glucagon-like peptide-1 agonist improved proliferation and differentiation of EPCs via upregulation of VEGF. The dipeptidyl peptidase-4 inhibitor sitagliptin [300] increased the circulating number of $\mathrm{CD} 34^{+}$cells and improved the adhesion ability of EPCs to the retinal vessels in Zucker diabetic fatty rats [301].

\subsection{Vitamin $D$}

Recently, it has been shown that the effects of vitamin D (1,25-dihydroxycolecalciferol) were not limited to the bone metabolism. In fact, the receptors for vitamin D (VDR) are present in several cell types, including endothelial cells. It has been suggested that vitamin D deficiency is a risk factor for the development of endothelial dysfunction [302]. Vitamin D supplementation can improve the endothelial function by regulating NO bioavailability, reducing oxidative stress and exerting anti-inflammatory effects [303]. However, the effects of vitamin D supplementation on EPCs functionality are relatively scarce. Supplementation with vitamin D increased the number of VDR on EPCs [304]. In patients with type-2 diabetes, vitamin $\mathrm{D}$ supplementation improved the colony forming capacity and the viability of EPCs. However, vitamin D supplementation seems to have no effect on EPCs angiogenesis markers expression in these patients [305].

\subsection{Other Biological Therapies}

\subsubsection{Supplementation of EPCs with Proangiogenic Factors}

Pretreatment of EPCs with proangiogenic growth factors, such as VEGF, basic fibroblast growth factor and platelet-derived growth factor, and overexpression of eNOS were able to improve angiogenesis and wound healing in diabetic mice [306,307] and also displayed antiatherogenic properties [307]. In addition, injection of EPCs isolated from patients with peripheral arterial disease, supplemented with the soluble CD146 angiogenic factor, improved the generation of new blood vessels and restored blood flow in an animal model of hindlimb ischemia [308].

\subsubsection{The Renin-Angiotensin-Aldosterone System and Endothelin}

The renin-angiotensin-aldosterone system (RAAS) and ET-1 represent two of the most potent vasopressor mechanisms $[309,310]$ and so play a major role in the regulation of the cardiovascular system. RAAS and ET-1 are interconnected. In fact, angiotensin II can affect the synthesis of ET-1 which in turn regulates the RAAS [311]. Blockade of the RAAS with angiotensin converting enzyme inhibitors or angiotensin receptor blockers has been shown to increase EPCs number in patients with type-2 diabetes [312]. Using a combination of statin and angiotensin receptor blocker amplified the effect of angiotensin receptor blocker alone on the EPCs number in patient with type-2 diabetes [313,314].

Up-regulation of ET-1 has been shown to increase the circulating EPCs number in patients with myocardial infarction and type-2 diabetes [315], and a correlation has been 
observed between reduced EPCs number and reduced plasma level of ET-1 in children with arterial hypertension [316].

\subsubsection{Lifestyle Modifications}

In diabetic mice, aerobic and resistance training increased PI3K and pAKT pathways, thus improving the proliferation and adherence capacities of EPCs [317]. In patients with MetS, exercise improved in vivo endothelial repair capacity of EPCs by increased NO production and reduced superoxide anion level [318]. Moreover, exercise combined to hypocaloric diet has led to weight reduction and so to increase in EPCs number and function in patients with CVD or type-2 diabetes [319].

\subsubsection{Treatment Using $\mathrm{H}_{2} \mathrm{~S}$ Donors}

It is important to maintain $\mathrm{H}_{2} \mathrm{~S}$ plasma concentration at physiological level in the nanomolar order to control blood pressure, to correct endothelial dysfunction, vascular inflammation and redox state, and to improve neovascularization and wound healing. An ideal $\mathrm{H}_{2} \mathrm{~S}$ donor should allow slow and gradual production and intracellular release of $\mathrm{H}_{2} \mathrm{~S}$. Several compounds have been developed. GYY4137 and AP39 are chemical agents developed as $\mathrm{H}_{2} \mathrm{~S}$ donors, with slow realizing functions. Intravenous or intraperitoneal administration of GYY4137 improved vasodilation in aortic, renal and cardiac arteries in a rat model of Nw-nitro-L-arginine methyl ester hydrochloride (L-NAME)-induced hypertension [320]. GYY4137 also reduced atherosclerotic plaque formation and improved endothelium-dependent vasodilation by reducing vascular inflammation and oxidative stress in ApoE-/- mice [321]. AP39 reduced systemic blood pressure, heart rate and arterial stiffness in L-NAME treated rats [322]. Thanks the positive interaction and synergistic action between $\mathrm{NO}$ and $\mathrm{H}_{2} \mathrm{~S}$, a hybrid donor of $\mathrm{NO}$ and $\mathrm{H}_{2} \mathrm{~S}$ has been synthesized, ZYZ803, which improved blood flow and vascular density related to femoral artery ligation in mice [323]. Sodium hydrosulfide (NaHS) and 4-hydroxylthio-benzamide have been administrated as $\mathrm{H}_{2} \mathrm{~S}$ diet supplementation in animal models and allowed to restore $\mathrm{H}_{2} \mathrm{~S}$ level and EPCs functions notably by stimulating angiogenic pathways $[214,215,223]$. NaHS injection in a rodent model of carotid artery injury was able to promote reendothelialization following vascular injury by enhancing eNOS-dependent EPCs mobilization [324].

Oral compounds able to produce endogenous $\mathrm{H}_{2} \mathrm{~S}$ have been developed. $\mathrm{N}$-acetylcysteine, used to enhance cellular levels of glutathione, rapidly cleaved in vivo to yield cysteine, has been proposed. However, to date, there is no published data. The sulfur amino acid taurine was shown to increase the expression of CSE $[325,326]$ and decrease blood pressure in patients with prehypertension.

Finally, natural compounds have been identified as a source of $\mathrm{H}_{2} \mathrm{~S}$, in particular polysulfides, such as garlic, which is considered as a natural medicine against hypertension. Polysulfides have been found to improve vasodilation properties, cardiac function and angiogenesis due to endogenous $\mathrm{H}_{2} \mathrm{~S}$ release [32-329].

\section{Conclusions}

Patients with MetS-related cardiometabolic disorders, and particularly individuals born after IUGR, display impaired number and functionality of EPCs, characterized by alterations in their circulating level and their migration, proliferation and angiogenesis properties. These alterations are related to oxidative stress, cellular senescence, inflammation, impaired angiogenic factors, hyperhomocysteinemia, and are under the control of epigenetic mechanisms. However, it is not yet clearly established whether the dysfunction of EPCs precede or is a consequence of MetS.

Some therapeutical approaches have been proposed to reverse the EPCs dysfunction related to MetS. In the last few years, the use of stem cells has emerged as promising for regenerative medicine because of their capacities to contribute to organ repair and regeneration throughout life. In particular, the EPCs have been identified as having a clinical potential, notably in vascular regenerative applications [330,331] in ischemic diseases, such 
as myocardial infarction and peripheral vascular disease, but also in metabolic diseases, pulmonary and systemic hypertension [332,333].

A better understanding of the contribution of EPCs dysfunction in the developmental programming of cardiometabolic disorders could therefore help to design promising therapeutical approaches to prevent or reverse the development of some of the major non-communicable diseases at adulthood.

Author Contributions: Conceptualization, C.Y. and A.-C.P.; validation, A.-C.P., J.-B.A., E.G. and C.Y.; writing — original draft preparation, C.Y. and A.-C.P.; writing—review and editing, A.-C.P., J.-B.A., E.G. and C.Y.; funding acquisition, C.Y. All authors have read and agreed to the published version of the manuscript.

Funding: This research was funded by grant from the "Association pour l'information et la recherche sur les maladies rénales génétiques" (AIRG-Suisse).

Institutional Review Board Statement: Not applicable.

Informed Consent Statement: Not applicable.

Acknowledgments: We are grateful to Jean-Pierre Guignard and AIRG-Suisse for their financial support. We thank warmly Ludovic Peyter for his contribution to figure preparation. We also thank Jean-François Tolsa and Umberto Simeoni for their helpful suggestions and support.

Conflicts of Interest: The authors declare no conflict of interest.

\section{References}

1. Spahis, S.; Borys, J.M.; Levy, E. Metabolic Syndrome as a Multifaceted Risk Factor for Oxidative Stress. Antioxid. Redox. Signal. 2017, 26, 445-461. [CrossRef]

2. Bonomini, F.; Rodella, L.F.; Rezzani, R. Metabolic syndrome, aging and involvement of oxidative stress. Aging Dis. 2015, 6, 109-120. [CrossRef]

3. Grundy, S.M.; Cleeman, J.I.; Daniels, S.R.; Donato, K.A.; Eckel, R.H.; Franklin, B.A.; Gordon, D.J.; Krauss, R.M.; Savage, P.J.; Smith, S.C., Jr.; et al. Diagnosis and management of the metabolic syndrome: An American Heart Association/National Heart, Lung, and Blood Institute Scientific Statement. Circulation 2005, 112, 2735-2752. [CrossRef]

4. Stefan, N.; Haring, H.U.; Cusi, K. Non-alcoholic fatty liver disease: Causes, diagnosis, cardiometabolic consequences, and treatment strategies. Lancet Diabetes Endocrinol. 2019, 7, 313-324. [CrossRef]

5. Sperling, L.S.; Mechanick, J.I.; Neeland, I.J.; Herrick, C.J.; Despres, J.P.; Ndumele, C.E.; Vijayaraghavan, K.; Handelsman, Y.; Puckrein, G.A.; Araneta, M.R.; et al. The CardioMetabolic Health Alliance: Working Toward a New Care Model for the Metabolic Syndrome. J. Am. Coll. Cardiol. 2015, 66, 1050-1067. [CrossRef]

6. Ritchie, S.A.; Connell, J.M. The link between abdominal obesity, metabolic syndrome and cardiovascular disease. Nutr. Metab. Cardiovasc. Dis. 2007, 17, 319-326. [CrossRef] [PubMed]

7. Berwick, Z.C.; Dick, G.M.; Tune, J.D. Heart of the matter: Coronary dysfunction in metabolic syndrome. J. Mol. Cell. Cardiol. 2012, 52, 848-856. [CrossRef] [PubMed]

8. Luscher, T.F.; Barton, M. Biology of the endothelium. Clin. Cardiol. 1997, 20, II-3-10. [CrossRef]

9. Martin, F.A.; Murphy, R.P.; Cummins, P.M. Thrombomodulin and the vascular endothelium: Insights into functional, regulatory, and therapeutic aspects. Am. J. Physiol. Heart Circ. Physiol. 2013, 304, H1585-97. [CrossRef]

10. Minshall, R.D.; Tiruppathi, C.; Vogel, S.M.; Malik, A.B. Vesicle formation and trafficking in endothelial cells and regulation of endothelial barrier function. Histochem. Cell. Biol. 2002, 117, 105-112. [CrossRef] [PubMed]

11. Vane, J.R.; Anggard, E.E.; Botting, R.M. Regulatory functions of the vascular endothelium. N. Engl. J. Med. 1990, 323, 27-36.

12. Deanfield, J.E.; Halcox, J.P.; Rabelink, T.J. Endothelial function and dysfunction: Testing and clinical relevance. Circulation 2007, 115, 1285-1295. [CrossRef]

13. Forstermann, U.; Sessa, W.C. Nitric oxide synthases: Regulation and function. Eur. Heart J. 2012, 33, 829-837. [CrossRef]

14. Flavahan, N.A. Atherosclerosis or lipoprotein-induced endothelial dysfunction. Potential mechanisms underlying reduction in EDRF/nitric oxide activity. Circulation 1992, 85, 1927-1938. [CrossRef]

15. Leeson, P.; Thorne, S.; Donald, A.; Mullen, M.; Clarkson, P.; Deanfield, J. Non-invasive measurement of endothelial function: Effect on brachial artery dilatation of graded endothelial dependent and independent stimuli. Heart 1997, 78, 22-27. [CrossRef]

16. Griendling, K.K.; FitzGerald, G.A. Oxidative stress and cardiovascular injury: Part I: Basic mechanisms and in vivo monitoring of ROS. Circulation 2003, 108, 1912-1916. [CrossRef]

17. Benjamin, E.J.; Larson, M.G.; Keyes, M.J.; Mitchell, G.F.; Vasan, R.S.; Keaney, J.F., Jr; Lehman, B.T.; Fan, S.; Osypiuk, E.; Vita, J.A. Clinical correlates and heritability of flow-mediated dilation in the community: The Framingham Heart Study. Circulation 2004, 109, 613-619. [CrossRef] 
18. Panza, J.A.; Quyyumi, A.A.; Brush, J.E., Jr.; Epstein, S.E. Abnormal endothelium-dependent vascular relaxation in patients with essential hypertension. N. Engl. J. Med. 1990, 323, 22-27. [CrossRef]

19. Brook, R.D.; Bard, R.L.; Rubenfire, M.; Ridker, P.M.; Rajagopalan, S. Usefulness of visceral obesity (waist/hip ratio) in predicting vascular endothelial function in healthy overweight adults. Am. J. Cardiol. 2001, 88, 1264-1269. [CrossRef]

20. Perticone, F.; Ceravolo, R.; Candigliota, M.; Ventura, G.; Iacopino, S.; Sinopoli, F.; Mattioli, P.L. Obesity and body fat distribution induce endothelial dysfunction by oxidative stress: Protective effect of vitamin C. Diabetes 2001, 50, 159-165. [CrossRef]

21. Arcaro, G.; Zamboni, M.; Rossi, L.; Turcato, E.; Covi, G.; Armellini, F.; Bosello, O.; Lechi, A. Body fat distribution predicts the degree of endothelial dysfunction in uncomplicated obesity. Int. J. Obes. Relat. Metab. Disord. 1999, 23, 936-942. [CrossRef]

22. McVeigh, G.E.; Brennan, G.M.; Johnston, G.D.; McDermott, B.J.; McGrath, L.T.; Henry, W.R.; Andrews, J.W.; Hayes, J.R. Impaired endothelium-dependent and independent vasodilation in patients with type 2 (non-insulin-dependent) diabetes mellitus. Diabetologia 1992, 35, 771-776. [PubMed]

23. Williams, S.B.; Cusco, J.A.; Roddy, M.A.; Johnstone, M.T.; Creager, M.A. Impaired nitric oxide-mediated vasodilation in patients with non-insulin-dependent diabetes mellitus. J. Am. Coll. Cardiol. 1996, 27, 567-574. [CrossRef]

24. Kim, J.A.; Montagnani, M.; Koh, K.K.; Quon, M.J. Reciprocal relationships between insulin resistance and endothelial dysfunction: Molecular and pathophysiological mechanisms. Circulation 2006, 113, 1888-1904. [CrossRef]

25. Fox, C.S. Cardiovascular disease risk factors, type 2 diabetes mellitus, and the Framingham Heart Study. Trends Cardiovasc. Med. 2010, 20, 90-95. [CrossRef]

26. Avogaro, A.; de Kreutzenberg, S.V.; Fadini, G. Endothelial dysfunction: Causes and consequences in patients with diabetes mellitus. Diabetes Res. Clin. Pract. 2008, 82, S94-S101. [CrossRef]

27. Giacco, F.; Brownlee, M. Oxidative stress and diabetic complications. Circ. Res. 2010, 107, 1058-1070. [CrossRef]

28. Tousoulis, D.; Papageorgiou, N.; Androulakis, E.; Siasos, G.; Latsios, G.; Tentolouris, K.; Stefanadis, C. Diabetes mellitus-associated vascular impairment: Novel circulating biomarkers and therapeutic approaches. J. Am. Coll. Cardiol. 2013, 62, 667-676. [CrossRef] [PubMed]

29. Arinc, H.; Sarli, B.; Baktir, A.O.; Saglam, H.; Demirci, E.; Dogan, Y.; Kurtul, S.; Karaman, H.; Erden, A.; Karaman, A. Serum gamma glutamyl transferase and alanine transaminase concentrations predict endothelial dysfunction in patients with non-alcoholic steatohepatitis. Ups. J. Med. Sci. 2013, 118, 228-234. [CrossRef]

30. Villanova, N.; Moscatiello, S.; Ramilli, S.; Bugianesi, E.; Magalotti, D.; Vanni, E.; Zoli, M.; Marchesini, G. Endothelial dysfunction and cardiovascular risk profile in nonalcoholic fatty liver disease. Hepatology 2005, 42, 473-480. [CrossRef]

31. Colak, Y.; Senates, E.; Yesil, A.; Yilmaz, Y.; Ozturk, O.; Doganay, L.; Coskunpinar, E.; Kahraman, O.T.; Mesci, B.; Ulasoglu, C.; et al. Assessment of endothelial function in patients with nonalcoholic fatty liver disease. Endocrine 2013, 43, 100-107. [CrossRef]

32. Asahara, T.; Masuda, H.; Takahashi, T.; Kalka, C.; Pastore, C.; Silver, M.; Kearne, M.; Magner, M.; Isner, J.M. Bone marrow origin of endothelial progenitor cells responsible for postnatal vasculogenesis in physiological and pathological neovascularization. Circ. Res. 1999, 85, 221-228. [CrossRef]

33. Murohara, T. Angiogenesis and vasculogenesis for therapeutic neovascularization. Nagoya J. Med. Sci. $2003,66,1-7$.

34. Werner, N.; Junk, S.; Laufs, U.; Link, A.; Walenta, K.; Bohm, M.; Nickenig, G. Intravenous transfusion of endothelial progenitor cells reduces neointima formation after vascular injury. Circ. Res. 2003, 93, e17-e24. [CrossRef]

35. Ingram, D.A.; Mead, L.E.; Tanaka, H.; Meade, V.; Fenoglio, A.; Mortell, K.; Pollok, K.; Ferkowicz, M.J.; Gilley, D.; Yoder, M.C. Identification of a novel hierarchy of endothelial progenitor cells using human peripheral and umbilical cord blood. Blood 2004, 104, 2752-2760. [CrossRef]

36. Ingram, D.A.; Mead, L.E.; Moore, D.B.; Woodard, W.; Fenoglio, A.; Yoder, M.C. Vessel wall-derived endothelial cells rapidly proliferate because they contain a complete hierarchy of endothelial progenitor cells. Blood 2005, 105, 2783-2786. [CrossRef]

37. Lin, Y.; Weisdorf, D.J.; Solovey, A.; Hebbel, R.P. Origins of circulating endothelial cells and endothelial outgrowth from blood. J. Clin. Investig. 2000, 105, 71-77. [CrossRef]

38. Duong, H.T.; Comhair, S.A.; Aldred, M.A.; Mavrakis, L.; Savasky, B.M.; Erzurum, S.C.; Asosingh, K. Pulmonary artery endothelium resident endothelial colony-forming cells in pulmonary arterial hypertension. Pulm. Circ. 2011, 1, 475-486. [CrossRef]

39. Alphonse, R.S.; Vadivel, A.; Zhong, S.; McConaghy, S.; Ohls, R.; Yoder, M.C.; Thebaud, B. The isolation and culture of endothelial colony-forming cells from human and rat lungs. Nat. Protoc. 2015, 10, 1697-1708. [CrossRef]

40. Solomon, I.; O’Reilly, M.; Ionescu, L.; Alphonse, R.S.; Rajabali, S.; Zhong, S.; Vadivel, A.; Shelley, W.C.; Yoder, M.C.; Thebaud, B. Functional Differences Between Placental Micro- and Macrovascular Endothelial Colony-Forming Cells. Stem Cells Transl. Med. 2016, 5, 291-300. [CrossRef]

41. Prasain, N.; Lee, M.R.; Vemula, S.; Meador, J.L.; Yoshimoto, M.; Ferkowicz, M.J.; Fett, A.; Gupta, M.; Rapp, B.M.; Saadatzadeh, M.R.; et al. Differentiation of human pluripotent stem cells to cells similar to cord-blood endothelial colony-forming cells. Nat. Biotechnol. 2014, 32, 1151-1157. [CrossRef] [PubMed]

42. Medina, R.J.; Barber, C.L.; Sabatier, F.; Dignat-George, F.; Melero-Martin, J.M.; Khosrotehrani, K.; Ohneda, O.; Randi, A.M.; Chan, J.K.Y.; Yamaguchi, T.; et al. Endothelial Progenitors: A Consensus Statement on Nomenclature. Stem Cells Transl. Med. 2017, 6, 1316-1320. [CrossRef] [PubMed]

43. Mund, J.A.; Estes, M.L.; Yoder, M.C.; Ingram, D.A., Jr.; Case, J. Flow cytometric identification and functional characterization of immature and mature circulating endothelial cells. Arterioscler. Thromb. Vasc. Biol. 2012, 32, 1045-1053. [CrossRef] 
44. Estes, M.L.; Mund, J.A.; Ingram, D.A.; Case, J. Identification of endothelial cells and progenitor cell subsets in human peripheral blood. Curr. Protoc. Cytom. 2010, 33, 1-11. [CrossRef]

45. Asahara, T.; Kawamoto, A.; Masuda, H. Concise review: Circulating endothelial progenitor cells for vascular medicine. Stem Cells 2011, 29, 1605-1650. [CrossRef]

46. Fadini, G.P.; Baesso, I.; Albiero, M.; Sartore, S.; Agostini, C.; Avogaro, A. Technical notes on endothelial progenitor cells: Ways to escape from the knowledge plateau. Atherosclerosis 2008, 197, 496-503. [CrossRef]

47. Boldicke, T.; Tesar, M.; Griesel, C.; Rohde, M.; Grone, H.J.; Waltenberger, J.; Kollet, O.; Lapidot, T.; Yayon, A.; Weich, H. AntiVEGFR-2 scFvs for cell isolation. Single-chain antibodies recognizing the human vascular endothelial growth factor receptor-2 (VEGFR-2/flk-1) on the surface of primary endothelial cells and preselected CD34+ cells from cord blood. Stem Cells 2001, 19, 24-36. [CrossRef] [PubMed]

48. Kunz, G.A.; Liang, G.; Cuculi, F.; Gregg, D.; Vata, K.C.; Shaw, L.K.; Goldschmidt-Clermont, P.J.; Dong, C.; Taylor, D.A.; Peterson, E.D. Circulating endothelial progenitor cells predict coronary artery disease severity. Am. Heart J. 2006, 152, 190-195. [CrossRef] [PubMed]

49. Keymel, S.; Kalka, C.; Rassaf, T.; Yeghiazarians, Y.; Kelm, M.; Heiss, C. Impaired endothelial progenitor cell function predicts age-dependent carotid intimal thickening. Basic Res. Cardiol. 2008, 103, 582-586. [CrossRef]

50. Iwasaki, H.; Kawamoto, A.; Ishikawa, M.; Oyamada, A.; Nakamori, S.; Nishimura, H.; Sadamoto, K.; Horii, M.; Matsumoto, T.; Murasawa, S.; et al. Dose-dependent contribution of CD34-positive cell transplantation to concurrent vasculogenesis and cardiomyogenesis for functional regenerative recovery after myocardial infarction. Circulation 2006, 113, 1311-1325. [CrossRef] [PubMed]

51. Yip, H.K.; Chang, L.T.; Sun, C.K.; Sheu, J.J.; Chiang, C.H.; Youssef, A.A.; Lee, F.Y.; Wu, C.J.; Fu, M. Autologous transplantation of bone marrow-derived endothelial progenitor cells attenuates monocrotaline-induced pulmonary arterial hypertension in rats. Crit. Care Med. 2008, 36, 873-880. [CrossRef]

52. Yip, H.K.; Chang, L.T.; Chang, W.N.; Lu, C.H.; Liou, C.W.; Lan, M.Y.; Liu, J.S.; Youssef, A.A.; Chang, H.W. Level and value of circulating endothelial progenitor cells in patients after acute ischemic stroke. Stroke 2008, 39, 69-74. [CrossRef] [PubMed]

53. Berezin, A.E.; Kremzer, A.A.; Berezina, T.A.; Martovitskaya, Y.V. The pattern of circulating microparticles in patients with diabetes mellitus with asymptomatic atherosclerosis. Acta Clin. Belg. 2016, 71, 38-45. [CrossRef]

54. Bakogiannis, C.; Tousoulis, D.; Androulakis, E.; Briasoulis, A.; Papageorgiou, N.; Vogiatzi, G.; Kampoli, A.M.; Charakida, M.; Siasos, G.; Latsios, G.; et al. Circulating endothelial progenitor cells as biomarkers for prediction of cardiovascular outcomes. Curr. Med. Chem. 2012, 19, 2597-2604. [CrossRef] [PubMed]

55. Berezin, A.E.; Kremzer, A.A. Circulating endothelial progenitor cells as markers for severity of ischemic chronic heart failure. J. Card. Fail. 2014, 20, 438-447. [CrossRef]

56. Berezin, A.E.; Kremzer, A.A.; Samura, T.A.; Berezina, T.A.; Martovitskaya, Y.V. Serum uric Acid predicts declining of circulating proangiogenic mononuclear progenitor cells in chronic heart failure patients. J. Cardiovasc. Thorac. Res. 2014, 6, 153-162 [CrossRef] [PubMed]

57. Egan, C.G.; Lavery, R.; Caporali, F.; Fondelli, C.; Laghi-Pasini, F.; Dotta, F.; Sorrentino, V. Generalised reduction of putative endothelial progenitors and CXCR4-positive peripheral blood cells in type 2 diabetes. Diabetologia 2008, 51, 1296-1305. [CrossRef] [PubMed]

58. Fadini, G.P. A reappraisal of the role of circulating (progenitor) cells in the pathobiology of diabetic complications. Diabetologia 2014, 57, 4-15. [CrossRef]

59. Langford-Smith, A.W.W.; Hasan, A.; Weston, R.; Edwards, N.; Jones, A.M.; Boulton, A.J.M.; Bowling, F.L.; Rashid, S.T.; Wilkinson, F.L.; Alexander, M.Y. Diabetic endothelial colony forming cells have the potential for restoration with glycomimetics. Sci. Rep. 2019, 9, 2309. [CrossRef]

60. Leicht, S.F.; Schwarz, T.M.; Hermann, P.C.; Seissler, J.; Aicher, A.; Heeschen, C. Adiponectin pretreatment counteracts the detrimental effect of a diabetic environment on endothelial progenitors. Diabetes 2011, 60, 652-661. [CrossRef]

61. Sorrentino, S.A.; Bahlmann, F.H.; Besler, C.; Muller, M.; Schulz, S.; Kirchhoff, N.; Doerries, C.; Horvath, T.; Limbourg, A.; Limbourg, F.; et al. Oxidant stress impairs in vivo reendothelialization capacity of endothelial progenitor cells from patients with type 2 diabetes mellitus: Restoration by the peroxisome proliferator-activated receptor-gamma agonist rosiglitazone. Circulation 2007, 116, 163-173. [CrossRef]

62. Tepper, O.M.; Galiano, R.D.; Capla, J.M.; Kalka, C.; Gagne, P.J.; Jacobowitz, G.R.; Levine, J.P.; Gurtner, G.C. Human endothelial progenitor cells from type II diabetics exhibit impaired proliferation, adhesion, and incorporation into vascular structures. Circulation 2002, 106, 2781-2786. [CrossRef]

63. Ii, M.; Takenaka, H.; Asai, J.; Ibusuki, K.; Mizukami, Y.; Maruyama, K.; Yoon, Y.S.; Wecker, A.; Luedemann, C.; Eaton, E.; et al. Endothelial progenitor thrombospondin-1 mediates diabetes-induced delay in reendothelialization following arterial injury. Circ. Res. 2006, 98, 697-704. [CrossRef] [PubMed]

64. Oikawa, A.; Siragusa, M.; Quaini, F.; Mangialardi, G.; Katare, R.G.; Caporali, A.; van Buul, J.D.; van Alphen, F.P.; Graiani, G.; Spinetti, G.; et al. Diabetes mellitus induces bone marrow microangiopathy. Arterioscler. Thromb. Vasc. Biol. 2010, $30,498-508$. [CrossRef] [PubMed] 
65. Albiero, M.; Menegazzo, L.; Boscaro, E.; Agostini, C.; Avogaro, A.; Fadini, G.P. Defective recruitment, survival and proliferation of bone marrow-derived progenitor cells at sites of delayed diabetic wound healing in mice. Diabetologia 2011, 54, 945-953. [CrossRef]

66. Kuliszewski, M.A.; Ward, M.R.; Kowalewski, J.W.; Smith, A.H.; Stewart, D.J.; Kutryk, M.J.; Leong-Poi, H. A direct comparison of endothelial progenitor cell dysfunction in rat metabolic syndrome and diabetes. Atherosclerosis 2013, 226, 58-66. [CrossRef]

67. Brownlee, M. The pathobiology of diabetic complications: A unifying mechanism. Diabetes 2005, 54, 1615-1625. [CrossRef] [PubMed]

68. Yue, W.S.; Lau, K.K.; Siu, C.W.; Wang, M.; Yan, G.H.; Yiu, K.H.; Tse, H.F. Impact of glycemic control on circulating endothelial progenitor cells and arterial stiffness in patients with type 2 diabetes mellitus. Cardiovasc. Diabetol. 2011, 10, 113. [CrossRef]

69. Fadini, G.P.; Miorin, M.; Facco, M.; Bonamico, S.; Baesso, I.; Grego, F.; Menegolo, M.; de Kreutzenberg, S.V.; Tiengo, A.; Agostini, C.; et al. Circulating endothelial progenitor cells are reduced in peripheral vascular complications of type 2 diabetes mellitus. $J$. Am. Coll. Cardiol. 2005, 45, 1449-1457. [CrossRef]

70. Fadini, G.P.; Sartore, S.; Albiero, M.; Baesso, I.; Murphy, E.; Menegolo, M.; Grego, F.; Vigili de Kreutzenberg, S.; Tiengo, A.; Agostini, C.; et al. Number and function of endothelial progenitor cells as a marker of severity for diabetic vasculopathy. Arterioscler. Thromb. Vasc. Biol. 2006, 26, 2140-2146. [CrossRef]

71. Chen, M.C.; Sheu, J.J.; Wang, P.W.; Chen, C.Y.; Kuo, M.C.; Hsieh, C.J.; Chen, J.F.; Chang, H.W. Complications impaired endothelial progenitor cell function in Type 2 diabetic patients with or without critical leg ischaemia: Implication for impaired neovascularization in diabetes. Diabet. Med. 2009, 26, 134-141. [CrossRef]

72. Moon, J.H.; Chae, M.K.; Kim, K.J.; Kim, H.M.; Cha, B.S.; Lee, H.C.; Kim, Y.J.; Lee, B.W. Decreased endothelial progenitor cells and increased serum glycated albumin are independently correlated with plaque-forming carotid artery atherosclerosis in type 2 diabetes patients without documented ischemic disease. Circ. J. 2012, 76, 2273-2279. [CrossRef] [PubMed]

73. Chen, Y.H.; Lin, S.J.; Lin, F.Y.; Wu, T.C.; Tsao, C.R.; Huang, P.H.; Liu, P.L.; Chen, Y.L.; Chen, J.W. High glucose impairs early and late endothelial progenitor cells by modifying nitric oxide-related but not oxidative stress-mediated mechanisms. Diabetes 2007, 56, 1559-1568. [CrossRef]

74. Werner, N.; Kosiol, S.; Schiegl, T.; Ahlers, P.; Walenta, K.; Link, A.; Bohm, M.; Nickenig, G. Circulating endothelial progenitor cells and cardiovascular outcomes. N. Engl. J. Med. 2005, 353, 999-1007. [CrossRef]

75. MacEneaney, O.J.; DeSouza, C.A.; Weil, B.R.; Kushner, E.J.; Van Guilder, G.P.; Mestek, M.L.; Greiner, J.J.; Stauffer, B.L. Prehypertension and endothelial progenitor cell function. J. Hum. Hypertens. 2011, 25, 57-62. [CrossRef]

76. Mandraffino, G.; Imbalzano, E.; Sardo, M.A.; D’Ascola, A.; Mamone, F.; Lo Gullo, A.; Alibrandi, A.; Loddo, S.; Mormina, E.; David, A.; et al. Circulating progenitor cells in hypertensive patients with different degrees of cardiovascular involvement. $J$. Hum. Hypertens. 2014, 28, 543-550. [CrossRef]

77. Skrzypkowska, M.W.; Ryba-Stanislawowska, M.E.; Slominski, B.; Gutknecht, P.G.; Siebert, J.; Mysliwska, J.M. Association of circulating progenitor cells with angiotensin II in newly diagnosed hypertensive patients. J. Hum. Hypertens. 2017, 32, 46-53. [CrossRef]

78. Marketou, M.E.; Kalyva, A.; Parthenakis, F.I.; Pontikoglou, C.; Maragkoudakis, S.; Kontaraki, J.E.; Chlouverakis, G.; Zacharis, E.A.; Patrianakos, A.; Papadaki, H.A.; et al. Circulating endothelial progenitor cells in hypertensive patients with increased arterial stiffness. J. Clin. Hypertens. 2014, 16, 295-300. [CrossRef]

79. Lewington, S.; Clarke, R.; Qizilbash, N.; Peto, R.; Collins, R.; Prospective Studies, C. Age-specific relevance of usual blood pressure to vascular mortality: A meta-analysis of individual data for one million adults in 61 prospective studies. Lancet 2002, 360, 1903-1913.

80. Britton, K.A.; Gaziano, J.M.; Djousse, L. Normal systolic blood pressure and risk of heart failure in US male physicians. Eur. J. Heart Fail. 2009, 11, 1129-1134. [CrossRef]

81. Jahangiry, L.; Farhangi, M.A.; Rezaei, F. Framingham risk score for estimation of 10-years of cardiovascular diseases risk in patients with metabolic syndrome. J. Health Popul. Nutr. 2017, 36, 36. [CrossRef]

82. Hill, J.M.; Zalos, G.; Halcox, J.P.; Schenke, W.H.; Waclawiw, M.A.; Quyyumi, A.A.; Finkel, T. Circulating endothelial progenitor cells, vascular function, and cardiovascular risk. N. Engl. J. Med. 2003, 348, 593-600. [CrossRef]

83. Vasa, M.; Fichtlscherer, S.; Aicher, A.; Adler, K.; Urbich, C.; Martin, H.; Zeiher, A.M.; Dimmeler, S. Number and migratory activity of circulating endothelial progenitor cells inversely correlate with risk factors for coronary artery disease. Circ. Res. 2001, 89, E1-E7. [CrossRef]

84. Lee, C.W.; Huang, P.H.; Huang, S.S.; Leu, H.B.; Huang, C.C.; Wu, T.C.; Chen, J.W.; Lin, S.J. Decreased circulating endothelial progenitor cell levels and function in essential hypertensive patients with electrocardiographic left ventricular hypertrophy. Hypertens. Res. 2011, 34, 999-1003. [CrossRef]

85. Bitterli, L.; Afan, S.; Buhler, S.; DiSanto, S.; Zwahlen, M.; Schmidlin, K.; Yang, Z.; Baumgartner, I.; Diehm, N.; Kalka, C. Endothelial progenitor cells as a biological marker of peripheral artery disease. Vasc. Med. 2016, 21, 3-11. [CrossRef]

86. Fadini, G.P.; Sartore, S.; Baesso, I.; Lenzi, M.; Agostini, C.; Tiengo, A.; Avogaro, A. Endothelial progenitor cells and the diabetic paradox. Diabetes Care 2006, 29, 714-716. [CrossRef]

87. Jialal, I.; Devaraj, S.; Singh, U.; Huet, B.A. Decreased number and impaired functionality of endothelial progenitor cells in subjects with metabolic syndrome: Implications for increased cardiovascular risk. Atherosclerosis 2010, 211, 297-302. [CrossRef] 
88. Muller-Ehmsen, J.; Braun, D.; Schneider, T.; Pfister, R.; Worm, N.; Wielckens, K.; Scheid, C.; Frommolt, P.; Flesch, M. Decreased number of circulating progenitor cells in obesity: Beneficial effects of weight reduction. Eur. Heart J. 2008, 29, 1560-1568. [CrossRef]

89. Heida, N.M.; Muller, J.P.; Cheng, I.F.; Leifheit-Nestler, M.; Faustin, V.; Riggert, J.; Hasenfuss, G.; Konstantinides, S.; Schafer, K. Effects of obesity and weight loss on the functional properties of early outgrowth endothelial progenitor cells. J. Am. Coll. Cardiol. 2010, 55, 357-367. [CrossRef]

90. Chen, Y.L.; Chang, C.L.; Sun, C.K.; Wu, C.J.; Tsai, T.H.; Chung, S.Y.; Chua, S.; Yeh, K.H.; Leu, S.; Sheu, J.J.; et al. Impact of obesity control on circulating level of endothelial progenitor cells and angiogenesis in response to ischemic stimulation. J. Transl. Med. 2012, 10, 86. [CrossRef]

91. Tsai, T.H.; Chai, H.T.; Sun, C.K.; Yen, C.H.; Leu, S.; Chen, Y.L.; Chung, S.Y.; Ko, S.F.; Chang, H.W.; Wu, C.J.; et al. Obesity suppresses circulating level and function of endothelial progenitor cells and heart function. J. Transl. Med. 2012, 10, 137. [CrossRef] [PubMed]

92. Chen, J.Z.; Zhang, F.R.; Tao, Q.M.; Wang, X.X.; Zhu, J.H.; Zhu, J.H. Number and activity of endothelial progenitor cells from peripheral blood in patients with hypercholesterolaemia. Clin. Sci. 2004, 107, 273-280. [CrossRef]

93. Rossi, F.; Bertone, C.; Montanile, F.; Miglietta, F.; Lubrano, C.; Gandini, L.; Santiemma, V. HDL cholesterol is a strong determinant of endothelial progenitor cells in hypercholesterolemic subjects. Microvasc. Res. 2010, 80, 274-279. [CrossRef] [PubMed]

94. Imanishi, T.; Hano, T.; Sawamura, T.; Nishio, I. Oxidized low-density lipoprotein induces endothelial progenitor cell senescence, leading to cellular dysfunction. Clin. Exp. Pharmacol. Physiol. 2004, 31, 407-413. [CrossRef]

95. Tarantino, G.; Saldalamacchia, G.; Conca, P.; Arena, A. Non-alcoholic fatty liver disease: Further expression of the metabolic syndrome. J. Gastroenterol. Hepatol. 2007, 22, 293-303. [CrossRef]

96. Kotronen, A.; Yki-Jarvinen, H. Fatty liver: A novel component of the metabolic syndrome. Arterioscler. Thromb. Vasc. Biol. 2008, 28, 27-38. [CrossRef]

97. Despres, J.P.; Lemieux, I.; Bergeron, J.; Pibarot, P.; Mathieu, P.; Larose, E.; Rodes-Cabau, J.; Bertrand, O.F.; Poirier, P. Abdominal obesity and the metabolic syndrome: Contribution to global cardiometabolic risk. Arterioscler. Thromb. Vasc. Biol. 2008, 28, 1039-1049. [CrossRef]

98. Vlachopoulos, C.; Manesis, E.; Baou, K.; Papatheodoridis, G.; Koskinas, J.; Tiniakos, D.; Aznaouridis, K.; Archimandritis, A.; Stefanadis, C. Increased arterial stiffness and impaired endothelial function in nonalcoholic Fatty liver disease: A pilot study. Am. J. Hypertens. 2010, 23, 1183-1189. [CrossRef]

99. Chiang, C.H.; Huang, P.H.; Chung, F.P.; Chen, Z.Y.; Leu, H.B.; Huang, C.C.; Wu, T.C.; Chen, J.W.; Lin, S.J. Decreased circulating endothelial progenitor cell levels and function in patients with nonalcoholic fatty liver disease. PLoS ONE 2012, 7, e31799. [CrossRef]

100. Gutierrez-Grobe, Y.; Gavilanes-Espinar, J.G.; Masso-Rojas, F.A.; Sanchez-Valle, V.; Paez-Arenas, A.; Ponciano-Rodriguez, G.; Chavez-Tapia, N.C.; Uribe, M.; Mendez-Sanchez, N. Metabolic syndrome and nonalcoholic fatty liver disease. The role of endothelial progenitor cells. Ann. Hepatol. 2013, 12, 908-914. [CrossRef]

101. Dean, R.T.; Fu, S.; Stocker, R.; Davies, M.J. Biochemistry and pathology of radical-mediated protein oxidation. Biochem. J. 1997, 324, 1-18. [CrossRef]

102. Landmesser, U.; Dikalov, S.; Price, S.R.; McCann, L.; Fukai, T.; Holland, S.M.; Mitch, W.E.; Harrison, D.G. Oxidation of tetrahydrobiopterin leads to uncoupling of endothelial cell nitric oxide synthase in hypertension. J. Clin. Investig. 2003, 111, 1201-1209. [CrossRef]

103. Versari, D.; Daghini, E.; Virdis, A.; Ghiadoni, L.; Taddei, S. Endothelium-dependent contractions and endothelial dysfunction in human hypertension. Br. J. Pharmacol. 2009, 157, 527-536. [CrossRef]

104. Watson, T.; Goon, P.K.; Lip, G.Y. Endothelial progenitor cells, endothelial dysfunction, inflammation, and oxidative stress in hypertension. Antioxid. Redox Signal. 2008, 10, 1079-1088. [CrossRef]

105. Schatteman, G.C.; Hanlon, H.D.; Jiao, C.; Dodds, S.G.; Christy, B.A. Blood-derived angioblasts accelerate blood-flow restoration in diabetic mice. J. Clin. Investig. 2000, 106, 571-578. [CrossRef] [PubMed]

106. Thum, T.; Fraccarollo, D.; Galuppo, P.; Tsikas, D.; Frantz, S.; Ertl, G.; Bauersachs, J. Bone marrow molecular alterations after myocardial infarction: Impact on endothelial progenitor cells. Cardiovasc. Res. 2006, 70, 50-60. [CrossRef]

107. Dernbach, E.; Urbich, C.; Brandes, R.P.; Hofmann, W.K.; Zeiher, A.M.; Dimmeler, S. Antioxidative stress-associated genes in circulating progenitor cells: Evidence for enhanced resistance against oxidative stress. Blood 2004, 104, 3591-3597. [CrossRef] [PubMed]

108. Collett, J.A.; Mehrotra, P.; Crone, A.; Shelley, W.C.; Yoder, M.C.; Basile, D.P. Endothelial colony-forming cells ameliorate endothelial dysfunction via secreted factors following ischemia-reperfusion injury. Am. J. Physiol. Renal. Physiol. 2017, 312, F897-F907. [CrossRef] [PubMed]

109. Tao, J.; Yang, Z.; Wang, J.M.; Wang, L.C.; Luo, C.F.; Tang, A.L.; Dong, Y.G.; Ma, H. Shear stress increases Cu/Zn SOD activity and mRNA expression in human endothelial progenitor cells. J. Hum. Hypertens. 2007, 21, 353-358. [CrossRef]

110. He, T.; Peterson, T.E.; Holmuhamedov, E.L.; Terzic, A.; Caplice, N.M.; Oberley, L.W.; Katusic, Z.S. Human endothelial progenitor cells tolerate oxidative stress due to intrinsically high expression of manganese superoxide dismutase. Arterioscler. Thromb. Vasc. Biol. 2004, 24, 2021-2027. [CrossRef] 
111. Lin, F.Y.; Tsao, N.W.; Shih, C.M.; Lin, Y.W.; Yeh, J.S.; Chen, J.W.; Nakagami, H.; Morishita, R.; Sawamura, T.; Huang, C.Y. The biphasic effects of oxidized-low density lipoprotein on the vasculogenic function of endothelial progenitor cells. PLOS ONE 2015, 10, e0123971. [CrossRef]

112. Tso, C.; Martinic, G.; Fan, W.H.; Rogers, C.; Rye, K.A.; Barter, P.J. High-density lipoproteins enhance progenitor-mediated endothelium repair in mice. Arterioscler. Thromb. Vasc. Biol. 2006, 26, 1144-1149. [CrossRef]

113. Beckman, K.B.; Ames, B.N. Endogenous oxidative damage of mtDNA. Mutat. Res. 1999, 424, 51-58. [CrossRef]

114. Murphy, M.P. Induction of mitochondrial ROS production by electrophilic lipids: A new pathway of redox signaling? Am. J. Physiol. Heart. Circ. Physiol. 2006, 290, H1754-H1755. [CrossRef]

115. Choi, J.W.; Son, S.M.; Mook-Jung, I.; Moon, Y.J.; Lee, J.Y.; Wang, K.C.; Kang, H.S.; Phi, J.H.; Choi, S.A.; Chong, S.; et al. Mitochondrial abnormalities related to the dysfunction of circulating endothelial colony-forming cells in moyamoya disease. J. Neurosurg. 2018, 129, 1151-1159. [CrossRef]

116. Lyons, C.J.; O’Brien, T. The Functionality of Endothelial-Colony-Forming Cells from Patients with Diabetes Mellitus. Cells 2020, 9 , 1731. [CrossRef]

117. Lopez-Otin, C.; Blasco, M.A.; Partridge, L.; Serrano, M.; Kroemer, G. The hallmarks of aging. Cell 2013, 153, 1194-1217. [CrossRef]

118. Georgakopoulou, E.A.; Tsimaratou, K.; Evangelou, K.; Fernandez Marcos, P.J.; Zoumpourlis, V.; Trougakos, I.P.; Kletsas, D.; Bartek, J.; Serrano, M.; Gorgoulis, V.G. Specific lipofuscin staining as a novel biomarker to detect replicative and stress-induced senescence. A method applicable in cryo-preserved and archival tissues. Aging 2013, 5, 37-50. [CrossRef]

119. Campisi, J.; d'Adda di Fagagna, F. Cellular senescence: When bad things happen to good cells. Nat. Rev. Mol. Cell. Biol. 2007, 8, 729-740. [CrossRef]

120. Campisi, J. Aging, cellular senescence, and cancer. Annu. Rev. Physiol. 2013, 75, 685-705. [CrossRef]

121. Martin-Ruiz, C.; Saretzki, G.; Petrie, J.; Ladhoff, J.; Jeyapalan, J.; Wei, W.; Sedivy, J.; von Zglinicki, T. Stochastic variation in telomere shortening rate causes heterogeneity of human fibroblast replicative life span. J. Biol. Chem. 2004, 279, 17826-17833. [CrossRef]

122. Vassallo, P.F.; Simoncini, S.; Ligi, I.; Chateau, A.L.; Bachelier, R.; Robert, S.; Morere, J.; Fernandez, S.; Guillet, B.; Marcelli, M.; et al. Accelerated senescence of cord blood endothelial progenitor cells in premature neonates is driven by SIRT1 decreased expression. Blood 2014, 123, 2116-2126. [CrossRef]

123. Coppe, J.P.; Desprez, P.Y.; Krtolica, A.; Campisi, J. The senescence-associated secretory phenotype: The dark side of tumor suppression. Annu. Rev. Pathol. 2010, 5, 99-118. [CrossRef]

124. Ingram, D.A.; Lien, I.Z.; Mead, L.E.; Estes, M.; Prater, D.N.; Derr-Yellin, E.; DiMeglio, L.A.; Haneline, L.S. In vitro hyperglycemia or a diabetic intrauterine environment reduces neonatal endothelial colony-forming cell numbers and function. Diabetes 2008, 57, 724-731. [CrossRef]

125. Carracedo, J.; Merino, A.; Briceno, C.; Soriano, S.; Buendia, P.; Calleros, L.; Rodriguez, M.; Martin-Malo, A.; Aljama, P.; Ramirez, R. Carbamylated low-density lipoprotein induces oxidative stress and accelerated senescence in human endothelial progenitor cells. FASEB J. 2011, 25, 1314-1322. [CrossRef]

126. Satoh, M.; Ishikawa, Y.; Takahashi, Y.; Itoh, T.; Minami, Y.; Nakamura, M. Association between oxidative DNA damage and telomere shortening in circulating endothelial progenitor cells obtained from metabolic syndrome patients with coronary artery disease. Atherosclerosis 2008, 198, 347-353. [CrossRef]

127. Alphonse, R.S.; Vadivel, A.; Fung, M.; Shelley, W.C.; Critser, P.J.; Ionescu, L.; O'Reilly, M.; Ohls, R.K.; McConaghy, S.; Eaton, F.; et al. Existence, functional impairment, and lung repair potential of endothelial colony-forming cells in oxygen-induced arrested alveolar growth. Circulation 2014, 129, 2144-2157. [CrossRef]

128. Lee, S.H.; Lee, J.H.; Han, Y.S.; Ryu, J.M.; Yoon, Y.M.; Han, H.J. Hypoxia accelerates vascular repair of endothelial colony-forming cells on ischemic injury via STAT3-BCL3 axis. Stem Cell Res. Ther. 2015, 6, 139. [CrossRef]

129. Tsukada, S.; Kwon, S.M.; Matsuda, T.; Jung, S.Y.; Lee, J.H.; Lee, S.H.; Masuda, H.; Asahara, T. Identification of mouse colonyforming endothelial progenitor cells for postnatal neovascularization: A novel insight highlighted by new mouse colony-forming assay. Stem Cell Res. Ther. 2013, 4, 20. [CrossRef]

130. Luque Contreras, D.; Vargas Robles, H.; Romo, E.; Rios, A.; Escalante, B. The role of nitric oxide in the post-ischemic revascularization process. Pharmacol. Ther. 2006, 112, 553-563. [CrossRef]

131. Duda, D.G.; Fukumura, D.; Jain, R.K. Role of eNOS in neovascularization: NO for endothelial progenitor cells. Trends Mol. Med. 2004, 10, 143-145. [CrossRef]

132. Aicher, A.; Heeschen, C.; Mildner-Rihm, C.; Urbich, C.; Ihling, C.; Technau-Ihling, K.; Zeiher, A.M.; Dimmeler, S. Essential role of endothelial nitric oxide synthase for mobilization of stem and progenitor cells. Nat. Med. 2003, 9, 1370-1376. [CrossRef] [PubMed]

133. Babaei, S.; Stewart, D.J. Overexpression of endothelial NO synthase induces angiogenesis in a co-culture model. Cardiovasc. Res. 2002, 55, 190-200. [CrossRef]

134. Aicher, A.; Zeiher, A.M.; Dimmeler, S. Mobilizing endothelial progenitor cells. Hypertension 2005, 45, 321-325. [CrossRef]

135. Heissig, B.; Werb, Z.; Rafii, S.; Hattori, K. Role of c-kit/Kit ligand signaling in regulating vasculogenesis. Thromb. Haemost. 2003, 90, 570-576. [CrossRef]

136. Thum, T.; Fraccarollo, D.; Schultheiss, M.; Froese, S.; Galuppo, P.; Widder, J.D.; Tsikas, D.; Ertl, G.; Bauersachs, J. Endothelial nitric oxide synthase uncoupling impairs endothelial progenitor cell mobilization and function in diabetes. Diabetes 2007, 56, 666-674. [CrossRef] 
137. Dimmeler, S.; Fleming, I.; Fisslthaler, B.; Hermann, C.; Busse, R.; Zeiher, A.M. Activation of nitric oxide synthase in endothelial cells by Akt-dependent phosphorylation. Nature 1999, 399, 601-605. [CrossRef]

138. Vasa, M.; Breitschopf, K.; Zeiher, A.M.; Dimmeler, S. Nitric oxide activates telomerase and delays endothelial cell senescence. Circ. Res. 2000, 87, 540-542. [CrossRef]

139. Hoetzer, G.L.; Irmiger, H.M.; Keith, R.S.; Westbrook, K.M.; DeSouza, C.A. Endothelial nitric oxide synthase inhibition does not alter endothelial progenitor cell colony forming capacity or migratory activity. J. Cardiovasc. Pharmacol. 2005, 46, 387-389. [CrossRef]

140. Li Calzi, S.; Purich, D.L.; Chang, K.H.; Afzal, A.; Nakagawa, T.; Busik, J.V.; Agarwal, A.; Segal, M.S.; Grant, M.B. Carbon monoxide and nitric oxide mediate cytoskeletal reorganization in microvascular cells via vasodilator-stimulated phosphoprotein phosphorylation: Evidence for blunted responsiveness in diabetes. Diabetes 2008, 57, 2488-2494. [CrossRef]

141. Segal, M.S.; Shah, R.; Afzal, A.; Perrault, C.M.; Chang, K.; Schuler, A.; Beem, E.; Shaw, L.C.; Li Calzi, S.; Harrison, J.K.; et al. Nitric oxide cytoskeletal-induced alterations reverse the endothelial progenitor cell migratory defect associated with diabetes. Diabetes 2006, 55, 102-109. [CrossRef]

142. Chen, Y.S.; Chen, K.H.; Liu, C.C.; Lee, C.T.; Yang, C.H.; Chuang, K.C.; Lin, C.R. Propofol-induced vascular permeability change is related to the nitric oxide signaling pathway and occludin phosphorylation. J. Biomed. Sci. 2007, 14, 629-636. [CrossRef]

143. Verma, S.; Szmitko, P.E.; Anderson, T.J. Endothelial function: Ready for prime time? Can. J. Cardiol. 2004, 20, 1335-1339.

144. Kalka, C.; Masuda, H.; Takahashi, T.; Gordon, R.; Tepper, O.; Gravereaux, E.; Pieczek, A.; Iwaguro, H.; Hayashi, S.I.; Isner, J.M.; et al. Vascular endothelial growth factor(165) gene transfer augments circulating endothelial progenitor cells in human subjects. Circ. Res. 2000, 86, 1198-1202. [CrossRef]

145. Young, P.P.; Hofling, A.A.; Sands, M.S. VEGF increases engraftment of bone marrow-derived endothelial progenitor cells (EPCs) into vasculature of newborn murine recipients. Proc. Natl. Acad. Sci. USA 2002, 99, 11951-11956. [CrossRef]

146. Dulak, J.; Jozkowicz, A.; Frick, M.; Alber, H.F.; Dichtl, W.; Schwarzacher, S.P.; Pachinger, O.; Weidinger, F. Vascular endothelial growth factor: Angiogenesis, atherogenesis or both? J. Am. Coll. Cardiol. 2001, 38, 2137-2138. [CrossRef]

147. Dulak, J.; Jozkowicz, A.; Dembinska-Kiec, A.; Guevara, I.; Zdzienicka, A.; Zmudzinska-Grochot, D.; Florek, I.; Wojtowicz, A.; Szuba, A.; Cooke, J.P. Nitric oxide induces the synthesis of vascular endothelial growth factor by rat vascular smooth muscle cells. Arterioscler. Thromb. Vasc. Biol. 2000, 20, 659-666. [CrossRef]

148. Kimura, H.; Esumi, H. Reciprocal regulation between nitric oxide and vascular endothelial growth factor in angiogenesis. Acta Biochim. Pol. 2003, 50, 49-59. [CrossRef]

149. Di, Y.; Zhang, D.; Hu, T.; Li, D. miR-23 regulate the pathogenesis of patients with coronary artery disease. Int J. Clin. Exp. Med. 2015, 8, 11759-11769.

150. Qin, W.; Xie, W.; Xia, N.; He, Q.; Sun, T. Silencing of Transient Receptor Potential Channel 4 Alleviates oxLDL-induced Angiogenesis in Human Coronary Artery Endothelial Cells by Inhibition of VEGF and NF-kappaB. Med. Sci. Monit. 2016, 22, 930-936. [CrossRef]

151. Li, H.; Zhang, X.; Guan, X.; Cui, X.; Wang, Y.; Chu, H.; Cheng, M. Advanced glycation end products impair the migration, adhesion and secretion potentials of late endothelial progenitor cells. Cardiovasc. Diabetol. 2012, 11, 46. [CrossRef] [PubMed]

152. Edwards, N.; Langford-Smith, A.W.W.; Wilkinson, F.L.; Alexander, M.Y. Endothelial Progenitor Cells: New Targets for Therapeutics for Inflammatory Conditions With High Cardiovascular Risk. Front. Med. 2018, 5, 200. [CrossRef] [PubMed]

153. Castejon, R.; Jimenez-Ortiz, C.; Rosado, S.; Tutor-Ureta, P.; Mellor-Pita, S.; Yebra-Bango, M. Metabolic syndrome is associated with decreased circulating endothelial progenitor cells and increased arterial stiffness in systemic lupus erythematosus. Lupus 2016, 25, 129-136. [CrossRef]

154. Mok, C.C. Metabolic syndrome and systemic lupus erythematosus: The connection. Expert Rev. Clin. Immunol. 2019, 15, 765-775. [CrossRef]

155. Rodriguez-Carrio, J.; Prado, C.; de Paz, B.; Lopez, P.; Gomez, J.; Alperi-Lopez, M.; Ballina-Garcia, F.J.; Suarez, A. Circulating endothelial cells and their progenitors in systemic lupus erythematosus and early rheumatoid arthritis patients. Rheumatology 2012, 51, 1775-1784. [CrossRef]

156. Rodriguez-Carrio, J.; de Paz, B.; Lopez, P.; Prado, C.; Alperi-Lopez, M.; Ballina-Garcia, F.J.; Suarez, A. IFNalpha serum levels are associated with endothelial progenitor cells imbalance and disease features in rheumatoid arthritis patients. PLoS ONE 2014, 9, e86069. [CrossRef]

157. Lee, P.Y.; Li, Y.; Richards, H.B.; Chan, F.S.; Zhuang, H.; Narain, S.; Butfiloski, E.J.; Sobel, E.S.; Reeves, W.H.; Segal, M.S. Type I interferon as a novel risk factor for endothelial progenitor cell depletion and endothelial dysfunction in systemic lupus erythematosus. Arthritis Rheum. 2007, 56, 3759-3769. [CrossRef]

158. Thacker, S.G.; Zhao, W.; Smith, C.K.; Luo, W.; Wang, H.; Vivekanandan-Giri, A.; Rabquer, B.J.; Koch, A.E.; Pennathur, S.; Davidson, A.; et al. Type I interferons modulate vascular function, repair, thrombosis, and plaque progression in murine models of lupus and atherosclerosis. Arthritis Rheum. 2012, 64, 2975-2985. [CrossRef]

159. Kahlenberg, J.M.; Thacker, S.G.; Berthier, C.C.; Cohen, C.D.; Kretzler, M.; Kaplan, M.J. Inflammasome activation of IL-18 results in endothelial progenitor cell dysfunction in systemic lupus erythematosus. J. Immunol. 2011, 187, 6143-6156. [CrossRef]

160. Chen, T.G.; Zhong, Z.Y.; Sun, G.F.; Zhou, Y.X.; Zhao, Y. Effects of tumour necrosis factor-alpha on activity and nitric oxide synthase of endothelial progenitor cells from peripheral blood. Cell Prolif. 2011, 44, 352-359. [CrossRef] 
161. Ceradini, D.J.; Kulkarni, A.R.; Callaghan, M.J.; Tepper, O.M.; Bastidas, N.; Kleinman, M.E.; Capla, J.M.; Galiano, R.D.; Levine, J.P.; Gurtner, G.C. Progenitor cell trafficking is regulated by hypoxic gradients through HIF-1 induction of SDF-1. Nat. Med. 2004, 10, 858-864. [CrossRef] [PubMed]

162. Fadini, G.P.; Madeddu, P.; Waltenberger, J.; Fiorina, P. Vascular stem and progenitor cells in diabetic complications. Exp. Diabetes Res. 2012, 2012, 580343. [CrossRef]

163. Fadini, G.P.; Sartore, S.; Schiavon, M.; Albiero, M.; Baesso, I.; Cabrelle, A.; Agostini, C.; Avogaro, A. Diabetes impairs progenitor cell mobilisation after hindlimb ischaemia-reperfusion injury in rats. Diabetologia 2006, 49, 3075-3084. [CrossRef]

164. Fadini, G.P.; Avogaro, A. Diabetes impairs mobilization of stem cells for the treatment of cardiovascular disease: A meta-regression analysis. Int. J. Cardiol. 2013, 168, 892-897. [CrossRef]

165. Gallagher, K.A.; Liu, Z.J.; Xiao, M.; Chen, H.; Goldstein, L.J.; Buerk, D.G.; Nedeau, A.; Thom, S.R.; Velazquez, O.C. Diabetic impairments in NO-mediated endothelial progenitor cell mobilization and homing are reversed by hyperoxia and SDF-1 alpha. $J$. Clin. Investig. 2007, 117, 1249-1259. [CrossRef]

166. Barwari, T.; Rienks, M.; Mayr, M. MicroRNA-21 and the Vulnerability of Atherosclerotic Plaques. Mol. Ther. 2018, 26, 938-940. [CrossRef]

167. Navickas, R.; Gal, D.; Laucevicius, A.; Taparauskaite, A.; Zdanyte, M.; Holvoet, P. Identifying circulating microRNAs as biomarkers of cardiovascular disease: A systematic review. Cardiovasc. Res. 2016, 111, 322-337. [CrossRef]

168. Qu, K.; Wang, Z.; Lin, X.L.; Zhang, K.; He, X.L.; Zhang, H. MicroRNAs: Key regulators of endothelial progenitor cell functions. Clin. Chim. Acta 2015, 448, 65-73. [CrossRef]

169. Ito, T.; Yagi, S.; Yamakuchi, M. MicroRNA-34a regulation of endothelial senescence. Biochem. Biophys. Res. Commun. 2010, 398, 735-740. [CrossRef]

170. Santulli, G. MicroRNAs and Endothelial (Dys) Function. J. Cell. Physiol. 2016, 231, 1638-1644. [CrossRef]

171. Meng, S.; Cao, J.T.; Zhang, B.; Zhou, Q.; Shen, C.X.; Wang, C.Q. Downregulation of microRNA-126 in endothelial progenitor cells from diabetes patients, impairs their functional properties, via target gene Spred-1. J. Mol. Cell. Cardiol. 2012, 53, 64-72. [CrossRef]

172. Meng, S.; Cao, J.; Zhang, X.; Fan, Y.; Fang, L.; Wang, C.; Lv, Z.; Fu, D.; Li, Y. Downregulation of microRNA-130a contributes to endothelial progenitor cell dysfunction in diabetic patients via its target Runx3. PLoS ONE 2013, 8, e68611. [CrossRef]

173. Wang, Y.; Zuo, Q.; Bi, Y.; Zhang, W.; Jin, J.; Zhang, L.; Zhang, Y.N.; Li, B. miR-31 Regulates Spermatogonial Stem Cells Meiosis via Targeting Stra8. J. Cell. Biochem. 2017, 118, 4844-4853. [CrossRef]

174. Lu, W.C.; Liu, C.J.; Tu, H.F.; Chung, Y.T.; Yang, C.C.; Kao, S.Y.; Chang, K.W.; Lin, S.C. miR-31 targets ARID1A and enhances the oncogenicity and stemness of head and neck squamous cell carcinoma. Oncotarget 2016, 7, 57254-57267. [CrossRef]

175. Wang, H.W.; Huang, T.S.; Lo, H.H.; Huang, P.H.; Lin, C.C.; Chang, S.J.; Liao, K.H.; Tsai, C.H.; Chan, C.H.; Tsai, C.F.; et al. Deficiency of the microRNA-31-microRNA-720 pathway in the plasma and endothelial progenitor cells from patients with coronary artery disease. Arterioscler. Thromb. Vasc. Biol. 2014, 34, 857-869. [CrossRef]

176. Zhao, T.; Li, J.; Chen, A.F. MicroRNA-34a induces endothelial progenitor cell senescence and impedes its angiogenesis via suppressing silent information regulator 1. Am. J. Physiol. Endocrinol. Metab. 2010, 299, E110-E116. [CrossRef]

177. Lian, W.; Hu, X.; Shi, R.; Han, S.; Cao, C.; Wang, K.; Li, M. MiR-31 regulates the function of diabetic endothelial progenitor cells by targeting Satb2. Acta Biochim. Biophys. Sin. 2018, 50, 336-344. [CrossRef]

178. Choi, S.W.; Friso, S. Epigenetics: A New Bridge between Nutrition and Health. Adv. Nutr. 2010, 1, 8-16. [CrossRef]

179. Wang, C.; Wang, F.; Li, Z.; Cao, Q.; Huang, L.; Chen, S. MeCP2-mediated epigenetic regulation in senescent endothelial progenitor cells. Stem Cell Res. Ther. 2018, 9, 87. [CrossRef]

180. Fraineau, S.; Palii, C.G.; McNeill, B.; Ritso, M.; Shelley, W.C.; Prasain, N.; Chu, A.; Vion, E.; Rieck, K.; Nilufar, S.; et al. Epigenetic Activation of Pro-angiogenic Signaling Pathways in Human Endothelial Progenitors Increases Vasculogenesis. Stem Cell Rep. 2017, 9, 1573-1587. [CrossRef]

181. Ohtani, K.; Vlachojannis, G.J.; Koyanagi, M.; Boeckel, J.N.; Urbich, C.; Farcas, R.; Bonig, H.; Marquez, V.E.; Zeiher, A.M.; Dimmeler, S. Epigenetic regulation of endothelial lineage committed genes in pro-angiogenic hematopoietic and endothelial progenitor cells. Circ. Res. 2011, 109, 1219-1229. [CrossRef]

182. McCully, K.S. Homocysteine and vascular disease. Nat. Med. 1996, 2, 386-389. [CrossRef]

183. Kang, S.S.; Wong, P.W.; Malinow, M.R. Hyperhomocyst(e)inemia as a risk factor for occlusive vascular disease. Annu. Rev. Nutr. 1992, 12, 279-298. [CrossRef]

184. Welch, G.N.; Loscalzo, J. Homocysteine and atherothrombosis. N. Engl. J. Med. 1998, 338, 1042-1050. [CrossRef]

185. Rasmussen, K.; Moller, J. Total homocysteine measurement in clinical practice. Ann. Clin. Biochem. 2000, 37, 627-648. [CrossRef]

186. Yang, Q.; He, G.W. Imbalance of Homocysteine and H2S: Significance, Mechanisms, and Therapeutic Promise in Vascular Injury. Oxid. Med. Cell. Longev. 2019, 2019, 7629673. [CrossRef]

187. Citi, V.; Martelli, A.; Gorica, E.; Brogi, S.; Testai, L.; Calderone, V. Role of hydrogen sulfide in endothelial dysfunction: Pathophysiology and therapeutic approaches. J. Adv. Res. 2021, 27, 99-113. [CrossRef]

188. Stampfer, M.J.; Malinow, M.R. Can lowering homocysteine levels reduce cardiovascular risk? N. Engl. J. Med. 1995, 332, 328-329. [CrossRef]

189. Dawson, H.; Collins, G.; Pyle, R.; Deep-Dixit, V.; Taub, D.D. The immunoregulatory effects of homocysteine and its intermediates on T-lymphocyte function. Mech. Ageing Dev. 2004, 125, 107-110. [CrossRef] 
190. Selhub, J.; Jacques, P.F.; Wilson, P.W.; Rush, D.; Rosenberg, I.H. Vitamin status and intake as primary determinants of homocysteinemia in an elderly population. JAMA 1993, 270, 2693-2698. [CrossRef]

191. Refsum, H.; Smith, A.D.; Ueland, P.M.; Nexo, E.; Clarke, R.; McPartlin, J.; Johnston, C.; Engbaek, F.; Schneede, J.; McPartlin, C.; et al. Facts and recommendations about total homocysteine determinations: An expert opinion. Clin. Chem. 2004, 50, 3-32. [CrossRef] [PubMed]

192. Ganguly, P.; Alam, S.F. Role of homocysteine in the development of cardiovascular disease. Nutr. J. 2015, 14, 6. [CrossRef]

193. Lentz, S.R.; Erger, R.A.; Dayal, S.; Maeda, N.; Malinow, M.R.; Heistad, D.D.; Faraci, F.M. Folate dependence of hyperhomocysteinemia and vascular dysfunction in cystathionine beta-synthase-deficient mice. Am. J. Physiol. Heart Circ. Physiol. 2000, 279, H970-H975. [CrossRef] [PubMed]

194. Ungvari, Z.; Pacher, P.; Rischak, K.; Szollar, L.; Koller, A. Dysfunction of nitric oxide mediation in isolated rat arterioles with methionine diet-induced hyperhomocysteinemia. Arterioscler. Thromb. Vasc. Biol. 1999, 19, 1899-1904. [CrossRef]

195. Lentz, S.R.; Sobey, C.G.; Piegors, D.J.; Bhopatkar, M.Y.; Faraci, F.M.; Malinow, M.R.; Heistad, D.D. Vascular dysfunction in monkeys with diet-induced hyperhomocyst(e)inemia. J. Clin. Investig. 1996, 98, 24-29. [CrossRef]

196. Widner, B.; Enzinger, C.; Laich, A.; Wirleitner, B.; Fuchs, D. Hyperhomocysteinemia, pteridines and oxidative stress. Curr. Drug Metab. 2002, 3, 225-232. [CrossRef]

197. Alvarez, B.; Demicheli, V.; Duran, R.; Trujillo, M.; Cervenansky, C.; Freeman, B.A.; Radi, R. Inactivation of human Cu, Zn superoxide dismutase by peroxynitrite and formation of histidinyl radical. Free Radic. Biol. Med. 2004, 37, 813-822. [CrossRef]

198. MacMillan-Crow, L.A.; Crow, J.P.; Thompson, J.A. Peroxynitrite-mediated inactivation of manganese superoxide dismutase involves nitration and oxidation of critical tyrosine residues. Biochemistry 1998, 37, 1613-1622. [CrossRef]

199. Tyagi, N.; Sedoris, K.C.; Steed, M.; Ovechkin, A.V.; Moshal, K.S.; Tyagi, S.C. Mechanisms of homocysteine-induced oxidative stress. Am. J. Physiol. Heart Circ. Physiol. 2005, 289, H2649-H2656. [CrossRef]

200. Mayo, J.N.; Beard, R.S., Jr.; Price, T.O.; Chen, C.H.; Erickson, M.A.; Ercal, N.; Banks, W.A.; Bearden, S.E. Nitrative stress in cerebral endothelium is mediated by mGluR5 in hyperhomocysteinemia. J. Cereb. Blood Flow Metab. 2012, 32, 825-834. [CrossRef]

201. Calcerrada, P.; Peluffo, G.; Radi, R. Nitric oxide-derived oxidants with a focus on peroxynitrite: Molecular targets, cellular responses and therapeutic implications. Curr. Pharm. Des. 2011, 17, 3905-3932. [CrossRef]

202. Szabo, C.; Mabley, J.G.; Moeller, S.M.; Shimanovich, R.; Pacher, P.; Virag, L.; Soriano, F.G.; Van Duzer, J.H.; Williams, W.; Salzman, A.L.; et al. Part I: Pathogenetic role of peroxynitrite in the development of diabetes and diabetic vascular complications: Studies with FP15, a novel potent peroxynitrite decomposition catalyst. Mol. Med. 2002, 8, 571-580. [CrossRef]

203. Chen, J.Z.; Zhu, J.H.; Wang, X.X.; Zhu, J.H.; Xie, X.D.; Sun, J.; Shang, Y.P.; Guo, X.G.; Dai, H.M.; Hu, S.J. Effects of homocysteine on number and activity of endothelial progenitor cells from peripheral blood. J. Mol. Cell. Cardiol. 2004, 36, 233-239. [CrossRef]

204. Zhu, J.; Wang, X.; Chen, J.; Sun, J.; Zhang, F. Reduced number and activity of circulating endothelial progenitor cells from patients with hyperhomocysteinemia. Arch. Med. Res. 2006, 37, 484-489.

205. Dong, Y.; Sun, Q.; Liu, T.; Wang, H.; Jiao, K.; Xu, J.; Liu, X.; Liu, H.; Wang, W. Nitrative Stress Participates in Endothelial Progenitor Cell Injury in Hyperhomocysteinemia. PLoS ONE 2016, 11, e0158672. [CrossRef]

206. Alam, M.M.; Mohammad, A.A.; Shuaib, U.; Wang, C.; Ghani, U.; Schwindt, B.; Todd, K.G.; Shuaib, A. Homocysteine reduces endothelial progenitor cells in stroke patients through apoptosis. J. Cereb. Blood Flow Metab. 2009, 29, 157-165. [CrossRef]

207. Noor, R.; Shuaib, U.; Wang, C.X.; Todd, K.; Ghani, U.; Schwindt, B.; Shuaib, A. High-density lipoprotein cholesterol regulates endothelial progenitor cells by increasing eNOS and preventing apoptosis. Atherosclerosis 2007, 192, 92-99. [CrossRef]

208. Behera, J.; Tyagi, S.C.; Tyagi, N. Hyperhomocysteinemia induced endothelial progenitor cells dysfunction through hypermethylation of CBS promoter. Biochem. Biophys. Res. Commun. 2019, 510, 135-141. [CrossRef]

209. Polhemus, D.J.; Lefer, D.J. Emergence of hydrogen sulfide as an endogenous gaseous signaling molecule in cardiovascular disease. Circ. Res. 2014, 114, 730-737. [CrossRef]

210. Ciccone, V.; Genah, S.; Morbidelli, L. Endothelium as a Source and Target of H2S to Improve Its Trophism and Function. Antioxidants 2021, 10, 486. [CrossRef]

211. Paul, B.D.; Snyder, S.H. H2S: A Novel Gasotransmitter that Signals by Sulfhydration. Trends Biochem. Sci. 2015, 40, 687-700. [CrossRef]

212. Beltowski, J. Synthesis, Metabolism, and Signaling Mechanisms of Hydrogen Sulfide: An Overview. Methods Mol. Biol. 2019, 2007, 1-8.

213. Cheng, Z.; Garikipati, V.N.; Nickoloff, E.; Wang, C.; Polhemus, D.J.; Zhou, J.; Benedict, C.; Khan, M.; Verma, S.K.; Rabinowitz, J.E.; et al. Restoration of Hydrogen Sulfide Production in Diabetic Mice Improves Reparative Function of Bone Marrow Cells. Circulation 2016, 134, 1467-1483. [CrossRef]

214. Cai, W.J.; Wang, M.J.; Moore, P.K.; Jin, H.M.; Yao, T.; Zhu, Y.C. The novel proangiogenic effect of hydrogen sulfide is dependent on Akt phosphorylation. Cardiovasc. Res. 2007, 76, 29-40. [CrossRef]

215. Papapetropoulos, A.; Pyriochou, A.; Altaany, Z.; Yang, G.; Marazioti, A.; Zhou, Z.; Jeschke, M.G.; Branski, L.K.; Herndon, D.N.; Wang, R.; et al. Hydrogen sulfide is an endogenous stimulator of angiogenesis. Proc. Natl. Acad. Sci. USA 2009, 106, 21972-21977. [CrossRef]

216. Szabo, C.; Papapetropoulos, A. Hydrogen sulphide and angiogenesis: Mechanisms and applications. Br. J. Pharmacol. 2011, 164, 853-865. [CrossRef] 
217. Zhao, W.; Zhang, J.; Lu, Y.; Wang, R. The vasorelaxant effect of $\mathrm{H}(2) \mathrm{S}$ as a novel endogenous gaseous K(ATP) channel opener. EMBO J. 2001, 20, 6008-6016. [CrossRef]

218. Sen, N.; Paul, B.D.; Gadalla, M.M.; Mustafa, A.K.; Sen, T.; Xu, R.; Kim, S.; Snyder, S.H. Hydrogen sulfide-linked sulfhydration of NF-kappaB mediates its antiapoptotic actions. Mol. Cell. 2012, 45, 13-24. [CrossRef]

219. Yang, G.; Zhao, K.; Ju, Y.; Mani, S.; Cao, Q.; Puukila, S.; Khaper, N.; Wu, L.; Wang, R. Hydrogen sulfide protects against cellular senescence via S-sulfhydration of Keap1 and activation of Nrf2. Antioxid. Redox Signal. 2013, 18, 1906-1919. [CrossRef]

220. Coletta, C.; Papapetropoulos, A.; Erdelyi, K.; Olah, G.; Modis, K.; Panopoulos, P.; Asimakopoulou, A.; Gero, D.; Sharina, I.; Martin, E.; et al. Hydrogen sulfide and nitric oxide are mutually dependent in the regulation of angiogenesis and endothelium-dependent vasorelaxation. Proc. Natl. Acad. Sci. USA 2012, 109, 9161-9166. [CrossRef]

221. Altaany, Z.; Ju, Y.; Yang, G.; Wang, R. The coordination of S-sulfhydration, S-nitrosylation, and phosphorylation of endothelial nitric oxide synthase by hydrogen sulfide. Sci. Signal. 2014, 7, ra87. [CrossRef]

222. Altaany, Z.; Yang, G.; Wang, R. Crosstalk between hydrogen sulfide and nitric oxide in endothelial cells. J. Cell. Mol. Med. 2013, 17, 879-888. [CrossRef]

223. Liu, F.; Chen, D.D.; Sun, X.; Xie, H.H.; Yuan, H.; Jia, W.; Chen, A.F. Hydrogen sulfide improves wound healing via restoration of endothelial progenitor cell functions and activation of angiopoietin-1 in type 2 diabetes. Diabetes 2014, 63, 1763-1778. [CrossRef]

224. Obi, S.; Yamamoto, K.; Ando, J. Effects of shear stress on endothelial progenitor cells. J. Biomed. Nanotechnol. 2014, 10, $2586-2597$. [CrossRef]

225. Obi, S.; Masuda, H.; Shizuno, T.; Sato, A.; Yamamoto, K.; Ando, J.; Abe, Y.; Asahara, T. Fluid shear stress induces differentiation of circulating phenotype endothelial progenitor cells. Am. J. Physiol. Cell. Physiol. 2012, 303, C595-C606. [CrossRef]

226. Xia, W.H.; Yang, Z.; Xu, S.Y.; Chen, L.; Zhang, X.Y.; Li, J.; Liu, X.; Qiu, Y.X.; Shuai, X.T.; Tao, J. Age-related decline in reendothelialization capacity of human endothelial progenitor cells is restored by shear stress. Hypertension 2012, 59, 1225-1231. [CrossRef]

227. Huang, B.; Chen, C.T.; Chen, C.S.; Wang, Y.M.; Hsieh, H.J.; Wang, D.L. Laminar shear flow increases hydrogen sulfide and activates a nitric oxide producing signaling cascade in endothelial cells. Biochem. Biophys. Res. Commun. 2015, 464, 1254-1259. [CrossRef]

228. Hu, Q.; Zhang, B.; Liu, Y.; Guo, Y.; Zhang, T.; Nie, R.; Ke, X.; Dong, X. The effect of fluid shear stress in hydrogen sulphide production and cystathionine gamma-lyase expression in human early endothelial progenitor cells. Ann. Transl. Med. 2020, 8 , 1318. [CrossRef]

229. Barker, D.J.; Osmond, C.; Golding, J.; Kuh, D.; Wadsworth, M.E. Growth in utero, blood pressure in childhood and adult life, and mortality from cardiovascular disease. BMJ 1989, 298, 564-567. [CrossRef]

230. Roseboom, T.; de Rooij, S.; Painter, R. The Dutch famine and its long-term consequences for adult health. Early Hum. Dev. 2006, 82, 485-491. [CrossRef]

231. Wang, Y.; Wang, X.; Kong, Y.; Zhang, J.H.; Zeng, Q. The Great Chinese Famine leads to shorter and overweight females in Chongqing Chinese population after 50 years. Obesity 2010, 18, 588-592. [CrossRef]

232. Cohen, E.; Wong, F.Y.; Horne, R.S.; Yiallourou, S.R. Intrauterine growth restriction: Impact on cardiovascular development and function throughout infancy. Pediatr. Res. 2016, 79, 821-830. [CrossRef]

233. Fattal-Valevski, A.; Bernheim, J.; Leitner, Y.; Redianu, B.; Bassan, H.; Harel, S. Blood pressure values in children with intrauterine growth retardation. Isr. Med. Assoc. J. 2001, 3, 805-808.

234. Rossi, P.; Tauzin, L.; Marchand, E.; Boussuges, A.; Gaudart, J.; Frances, Y. Respective roles of preterm birth and fetal growth restriction in blood pressure and arterial stiffness in adolescence. J. Adolesc. Health 2011, 48, 520-522. [CrossRef]

235. Nilsson, P.M.; Ostergren, P.O.; Nyberg, P.; Soderstrom, M.; Allebeck, P. Low birth weight is associated with elevated systolic blood pressure in adolescence: A prospective study of a birth cohort of 149378 Swedish boys. J. Hypertens. 1997, 15, 1627-1631. [CrossRef]

236. Leon, D.A.; Johansson, M.; Rasmussen, F. Gestational age and growth rate of fetal mass are inversely associated with systolic blood pressure in young adults: An epidemiologic study of 165,136 Swedish men aged 18 years. Am. J. Epidemiol. 2000, 152, 8. [CrossRef]

237. Curhan, G.C.; Chertow, G.M.; Willett, W.C.; Spiegelman, D.; Colditz, G.A.; Manson, J.E.; Speizer, F.E.; Stampfer, M.J. Birth weight and adult hypertension and obesity in women. Circulation 1996, 94, 1310-1315. [CrossRef]

238. Law, C.M.; Shiell, A.W. Is blood pressure inversely related to birth weight? The strength of evidence from a systematic review of the literature. J. Hypertens. 1996, 14, 935-941. [CrossRef]

239. Martyn, C.N.; Barker, D.J.; Jespersen, S.; Greenwald, S.; Osmond, C.; Berry, C. Growth in utero, adult blood pressure, and arterial compliance. Br. Heart J. 1995, 73, 6. [CrossRef]

240. Yzydorczyk, C.; Armengaud, J.B.; Peyter, A.C.; Chehade, H.; Cachat, F.; Juvet, C.; Siddeek, B.; Simoncini, S.; Sabatier, F.; Dignat-George, F.; et al. Endothelial dysfunction in individuals born after fetal growth restriction: Cardiovascular and renal consequences and preventive approaches. J. Dev. Orig. Health Dis. 2017, 8, 1-17. [CrossRef] [PubMed]

241. Leeson, C.; Whincup, P.; Cook, D.; Donald, A.; Papacosta, O.; Lucas, A.; Deanfield, J. Flow-mediated dilation in 9- to 11-year-old children: The influence of intrauterine and childhood factors. Circulation 1997, 96, 2233-2238. [CrossRef]

242. Martin, H.; Gazelius, B.; Norman, M. Impaired acetylcholine-induced vascular relaxation in low birth weight infants: Implications for adult hypertension? Pediatr. Res. 2000, 47, 457-462. [CrossRef] 
243. Martyn, C.N.; Greenwald, S.E. Impaired synthesis of elastin in walls of aorta and large conduit arteries during early development as an initiating event in pathogenesis of systemic hypertension. Lancet 1997, 350, 953-955. [CrossRef]

244. Joo Turoni, C.; Chaila, Z.; Chahla, R.; Bazan de Casella, M.C.; Peral de Bruno, M. Vascular Function in Children with Low Birthweight and Its Relationship with Early Markers of Cardiovascular Risk. Horm. Res. Paediatr. 2016, 85, 396-405. [CrossRef]

245. Krause, B.J.; Costello, P.M.; Munoz-Urrutia, E.; Lillycrop, K.A.; Hanson, M.A.; Casanello, P. Role of DNA methyltransferase 1 on the altered eNOS expression in human umbilical endothelium from intrauterine growth restricted fetuses. Epigenetics 2013, 8 , 944-952. [CrossRef]

246. Caniuguir, A.; Krause, B.J.; Hernandez, C.; Uauy, R.; Casanello, P. Markers of early endothelial dysfunction in intrauterine growth restriction-derived human umbilical vein endothelial cells revealed by 2D-DIGE and mass spectrometry analyses. Placenta 2016, 41, 14-26. [CrossRef]

247. Grandvuillemin, I.; Buffat, C.; Boubred, F.; Lamy, E.; Fromonot, J.; Charpiot, P.; Simoncini, S.; Sabatier, F.; Dignat-George, F.; Peyter, A.C.; et al. Arginase up-regulation and eNOS uncoupling contribute to impaired endothelium-dependent vasodilation in a rat model of intrauterine growth restriction. Am. J. Physiol. Regul. Integr. Comp. Physiol. 2018, 315, R509-R520. [CrossRef]

248. Cambonie, G.; Comte, B.; Yzydorczyk, C.; Ntimbane, T.; Germain, N.; Le, N.L.; Pladys, P.; Gauthier, C.; Lahaie, I.; Abran, D.; et al. Antenatal antioxidant prevents adult hypertension, vascular dysfunction, and microvascular rarefaction associated with in utero exposure to a low-protein diet. Am. J. Physiol. Regul. Integr. Comp. Physiol. 2007, 292, R1236-R1245. [CrossRef]

249. Yzydorczyk, C.; Comte, B.; Cambonie, G.; Lavoie, J.C.; Germain, N.; Ting Shun, Y.; Wolff, J.; Deschepper, C.; Touyz, R.M.; LelievrePegorier, M.; et al. Neonatal oxygen exposure in rats leads to cardiovascular and renal alterations in adulthood. Hypertension 2008, 52, 889-895. [CrossRef]

250. Hales, C.N.; Barker, D.J.; Clark, P.M.; Cox, L.J.; Fall, C.; Osmond, C.; Winter, P.D. Fetal and infant growth and impaired glucose tolerance at age 64. BMJ 1991, 303, 1019-1022. [CrossRef]

251. Zarrati, M.; Shidfar, F.; Razmpoosh, E.; Nezhad, F.N.; Keivani, H.; Hemami, M.R.; Asemi, Z. Does low birth weight predict hypertension and obesity in schoolchildren? Ann. Nutr. Metab. 2013, 63, 69-76. [CrossRef]

252. Ramadhani, M.K.; Grobbee, D.E.; Bots, M.L.; Castro Cabezas, M.; Vos, L.E.; Oren, A.; Uiterwaal, C.S. Lower birth weight predicts metabolic syndrome in young adults: The Atherosclerosis Risk in Young Adults (ARYA)-study. Atherosclerosis 2006, 184, 21-27. [CrossRef]

253. Nobili, V.; Marcellini, M.; Marchesini, G.; Vanni, E.; Manco, M.; Villani, A.; Bugianesi, E. Intrauterine growth retardation, insulin resistance, and nonalcoholic fatty liver disease in children. Diabetes Care 2007, 30, 2638-2640. [CrossRef]

254. Fraser, A.; Ebrahim, S.; Davey Smith, G.; Lawlor, D.A. The associations between height components (leg and trunk length) and adult levels of liver enzymes. J. Epidemiol. Community Health 2008, 62, 48-53. [CrossRef]

255. Meister, B.; Totsch, M.; Mayr, A.; Widschwendter, M.; Huter, O.; Sperl, W. Identification of CD34+ cord blood cells and their subpopulations in preterm and term neonates using three-color flow cytometry. Biol. Neonate 1994, 66, 272-279. [CrossRef]

256. Borghesi, A.; Massa, M.; Campanelli, R.; Bollani, L.; Tzialla, C.; Figar, T.A.; Ferrari, G.; Bonetti, E.; Chiesa, G.; de Silvestri, A.; et al. Circulating endothelial progenitor cells in preterm infants with bronchopulmonary dysplasia. Am. J. Respir. Crit. Care Med. 2009, 180, 540-546. [CrossRef]

257. Calcaterra, F.; Taddeo, A.; Colombo, E.; Cappelletti, M.; Martinelli, A.; Calabrese, S.; Mavilio, D.; Cetin, I.; Della Bella, S. Reduction of maternal circulating endothelial progenitor cells in human pregnancies with intrauterine growth restriction. Placenta 2014, 35, 431-436. [CrossRef]

258. Monga, R.; Buck, S.; Sharma, P.; Thomas, R.; Chouthai, N.S. Effect of preeclampsia and intrauterine growth restriction on endothelial progenitor cells in human umbilical cord blood. J. Matern. Fetal Neonatal. Med. 2012, 25, 2385-2389. [CrossRef]

259. Ligi, I.; Simoncini, S.; Tellier, E.; Vassallo, P.F.; Sabatier, F.; Guillet, B.; Lamy, E.; Sarlon, G.; Quemener, C.; Bikfalvi, A.; et al. A switch toward angiostatic gene expression impairs the angiogenic properties of endothelial progenitor cells in low birth weight preterm infants. Blood 2011, 118, 1699-1709. [CrossRef]

260. Simoncini, S.; Chateau, A.L.; Robert, S.; Todorova, D.; Yzydorczyk, C.; Lacroix, R.; Ligi, I.; Louis, L.; Bachelier, R.; Simeoni, U.; et al. Biogenesis of Pro-senescent Microparticles by Endothelial Colony Forming Cells from Premature Neonates is driven by SIRT1-Dependent Epigenetic Regulation of MKK6. Sci. Rep. 2017, 7, 8277. [CrossRef]

261. Darby, J.R.T.; Varcoe, T.J.; Orgeig, S.; Morrison, J.L. Cardiorespiratory consequences of intrauterine growth restriction: Influence of timing, severity and duration of hypoxaemia. Theriogenology 2020, 150, 84-95. [CrossRef]

262. Pike, K.; Jane Pillow, J.; Lucas, J.S. Long term respiratory consequences of intrauterine growth restriction. Semin. Fetal Neonatal. Med. 2012, 17, 92-98. [CrossRef] [PubMed]

263. Briana, D.D.; Malamitsi-Puchner, A. Small for gestational age birth weight: Impact on lung structure and function. Paediatr. Respir. Rev. 2013, 14, 256-262. [CrossRef]

264. Zana-Taieb, E.; Pham, H.; Franco-Montoya, M.L.; Jacques, S.; Letourneur, F.; Baud, O.; Jarreau, P.H.; Vaiman, D. Impaired alveolarization and intra-uterine growth restriction in rats: A postnatal genome-wide analysis. J. Pathol. 2015, 235, 420-430. [CrossRef] [PubMed]

265. Xu, X.F.; Lv, Y.; Gu, W.Z.; Tang, L.L.; Wei, J.K.; Zhang, L.Y.; Du, L.Z. Epigenetics of hypoxic pulmonary arterial hypertension following intrauterine growth retardation rat: Epigenetics in PAH following IUGR. Respir. Res. 2013, 14, 20. [CrossRef] 
266. Junhui, Z.; Xingxiang, W.; Guosheng, F.; Yunpeng, S.; Furong, Z.; Junzhu, C. Reduced number and activity of circulating endothelial progenitor cells in patients with idiopathic pulmonary arterial hypertension. Respir. Med. 2008, 102, 1073-1079. [CrossRef]

267. Diller, G.P.; van Eijl, S.; Okonko, D.O.; Howard, L.S.; Ali, O.; Thum, T.; Wort, S.J.; Bedard, E.; Gibbs, J.S.; Bauersachs, J.; et al. Circulating endothelial progenitor cells in patients with Eisenmenger syndrome and idiopathic pulmonary arterial hypertension. Circulation 2008, 117, 3020-3030. [CrossRef]

268. Assad, T.R.; Hemnes, A.R. Metabolic Dysfunction in Pulmonary Arterial Hypertension. Curr. Hypertens. Rep. 2015, 17, 20. [CrossRef]

269. Renaud, S.; de Lorgeril, M. Wine, alcohol, platelets, and the French paradox for coronary heart disease. Lancet 1992, 339, 1523-1526. [CrossRef]

270. Renaud, S.C.; Gueguen, R.; Schenker, J.; d'Houtaud, A. Alcohol and mortality in middle-aged men from eastern France. Epidemiology 1998, 9, 184-188. [CrossRef]

271. Weiskirchen, S.; Weiskirchen, R. Resveratrol: How Much Wine Do You Have to Drink to Stay Healthy? Adv. Nutr. 2016, 7, 706-718. [CrossRef]

272. Piotrowska, H.; Kucinska, M.; Murias, M. Biological activity of piceatannol: Leaving the shadow of resveratrol. Mutat. Res. 2012, 750, 60-82. [CrossRef] [PubMed]

273. Mei, Y.Z.; Liu, R.X.; Wang, D.P.; Wang, X.; Dai, C.C. Biocatalysis and biotransformation of resveratrol in microorganisms. Biotechnol. Lett. 2015, 37, 9-18. [CrossRef] [PubMed]

274. Chung, J.H.; Manganiello, V.; Dyck, J.R. Resveratrol as a calorie restriction mimetic: Therapeutic implications. Trends Cell. Biol. 2012, 22, 546-554. [CrossRef]

275. Baur, J.A.; Sinclair, D.A. Therapeutic potential of resveratrol: The in vivo evidence. Nat. Rev. Drug Discov. 2006, 5, 493-506. [CrossRef]

276. Schmitt, C.A.; Heiss, E.H.; Dirsch, V.M. Effect of resveratrol on endothelial cell function: Molecular mechanisms. Biofactors 2010, 36, 342-349. [CrossRef]

277. Wang, H.; Yang, Y.J.; Qian, H.Y.; Zhang, Q.; Xu, H.; Li, J.J. Resveratrol in cardiovascular disease: What is known from current research? Heart Fail. Rev. 2012, 17, 437-448. [CrossRef]

278. Dyck, G.J.B.; Raj, P.; Zieroth, S.; Dyck, J.R.B.; Ezekowitz, J.A. The Effects of Resveratrol in Patients with Cardiovascular Disease and Heart Failure: A Narrative Review. Int. J. Mol. Sci. 2019, 20, 904. [CrossRef]

279. Wang, X.B.; Huang, J.; Zou, J.G.; Su, E.B.; Shan, Q.J.; Yang, Z.J.; Cao, K.J. Effects of resveratrol on number and activity of endothelial progenitor cells from human peripheral blood. Clin. Exp. Pharmacol. Physiol. 2007, 34, 1109-1115. [PubMed]

280. Wallerath, T.; Deckert, G.; Ternes, T.; Anderson, H.; Li, H.; Witte, K.; Forstermann, U. Resveratrol, a polyphenolic phytoalexin present in red wine, enhances expression and activity of endothelial nitric oxide synthase. Circulation 2002, 106, 1652-1658. [CrossRef] [PubMed]

281. Gracia-Sancho, J.; Villarreal, G., Jr.; Zhang, Y.; Garcia-Cardena, G. Activation of SIRT1 by resveratrol induces KLF2 expression conferring an endothelial vasoprotective phenotype. Cardiovasc. Res. 2010, 85, 514-519. [CrossRef]

282. Wu, H.; Chen, Z.; Chen, J.Z.; Xie, J.; Xu, B. Resveratrol Improves Tube Formation in AGE-Induced Late Endothelial Progenitor Cells by Suppressing Syndecan-4 Shedding. Oxid. Med. Cell. Longev. 2018, 2018, 9045976. [CrossRef]

283. Xia, N.; Daiber, A.; Forstermann, U.; Li, H. Antioxidant effects of resveratrol in the cardiovascular system. Br. J. Pharmacol. 2017, 174, 1633-1646. [CrossRef] [PubMed]

284. Xia, L.; Wang, X.X.; Hu, X.S.; Guo, X.G.; Shang, Y.P.; Chen, H.J.; Zeng, C.L.; Zhang, F.R.; Chen, J.Z. Resveratrol reduces endothelial progenitor cells senescence through augmentation of telomerase activity by Akt-dependent mechanisms. Br. J. Pharmacol. 2008, 155, 387-394. [CrossRef]

285. Wang, X.B.; Zhu, L.; Huang, J.; Yin, Y.G.; Kong, X.Q.; Rong, Q.F.; Shi, A.W.; Cao, K.J. Resveratrol-induced augmentation of telomerase activity delays senescence of endothelial progenitor cells. Chin. Med. J. 2011, 124, 4310-4315.

286. Wu, H.; Li, G.N.; Xie, J.; Li, R.; Chen, Q.H.; Chen, J.Z.; Wei, Z.H.; Kang, L.N.; Xu, B. Resveratrol ameliorates myocardial fibrosis by inhibiting ROS/ERK/TGF-beta/periostin pathway in STZ-induced diabetic mice. BMC Cardiovasc. Disord. 2016, 16, 5. [CrossRef] [PubMed]

287. Spanier, G.; Xu, H.; Xia, N.; Tobias, S.; Deng, S.; Wojnowski, L.; Forstermann, U.; Li, H. Resveratrol reduces endothelial oxidative stress by modulating the gene expression of superoxide dismutase 1 (SOD1), glutathione peroxidase 1 (GPx1) and NADPH oxidase subunit (Nox4). J. Physiol. Pharmacol. 2009, 60, 111-116.

288. Rena, G.; Hardie, D.G.; Pearson, E.R. The mechanisms of action of metformin. Diabetologia 2017, 60, 1577-1585. [CrossRef]

289. Liao, Y.F.; Chen, L.L.; Zeng, T.S.; Li, Y.M.; Fan, Y.; Hu, L.J.; Ling, Y. Number of circulating endothelial progenitor cells as a marker of vascular endothelial function for type 2 diabetes. Vasc. Med. 2010, 15, 279-285. [CrossRef]

290. Zhou, G.; Myers, R.; Li, Y.; Chen, Y.; Shen, X.; Fenyk-Melody, J.; Wu, M.; Ventre, J.; Doebber, T.; Fujii, N.; et al. Role of AMP-activated protein kinase in mechanism of metformin action. J. Clin. Investig. 2001, 108, 1167-1174. [CrossRef]

291. Musi, N.; Hirshman, M.F.; Nygren, J.; Svanfeldt, M.; Bavenholm, P.; Rooyackers, O.; Zhou, G.; Williamson, J.M.; Ljunqvist, O.; Efendic, S.; et al. Metformin increases AMP-activated protein kinase activity in skeletal muscle of subjects with type 2 diabetes. Diabetes 2002, 51, 2074-2081. [CrossRef] 
292. Kao, J.; Tobis, J.; McClelland, R.L.; Heaton, M.R.; Davis, B.R.; Holmes, D.R., Jr.; Currier, J.W. Investigators in the Prevention of Restenosis With Tranilast and its Outcomes Trial. Relation of metformin treatment to clinical events in diabetic patients undergoing percutaneous intervention. Am. J. Cardiol. 2004, 93, 1347-1350. [CrossRef]

293. Zheng, Z.; Chen, H.; Li, J.; Li, T.; Zheng, B.; Zheng, Y.; Jin, H.; He, Y.; Gu, Q.; Xu, X. Sirtuin 1-mediated cellular metabolic memory of high glucose via the LKB1/AMPK/ROS pathway and therapeutic effects of metformin. Diabetes 2012, 61, 217-228. [CrossRef]

294. Arunachalam, G.; Samuel, S.M.; Marei, I.; Ding, H.; Triggle, C.R. Metformin modulates hyperglycaemia-induced endothelial senescence and apoptosis through SIRT1. Br. J. Pharmacol. 2014, 171, 523-535. [CrossRef] [PubMed]

295. Bakhashab, S.; Ahmed, F.W.; Schulten, H.J.; Bashir, A.; Karim, S.; Al-Malki, A.L.; Gari, M.A.; Abuzenadah, A.M.; Chaudhary, A.G.; Alqahtani, M.H.; et al. Metformin improves the angiogenic potential of human CD34(+) cells co-incident with downregulating CXCL10 and TIMP1 gene expression and increasing VEGFA under hyperglycemia and hypoxia within a therapeutic window for myocardial infarction. Cardiovasc. Diabetol. 2016, 15, 27. [CrossRef]

296. Haendeler, J.; Dimmeler, S. Inseparably tied: Functional and antioxidative capacity of endothelial progenitor cells. Circ. Res. 2006, 98, 157-158. [CrossRef]

297. Formoso, G.; De Filippis, E.A.; Michetti, N.; Di Fulvio, P.; Pandolfi, A.; Bucciarelli, T.; Ciabattoni, G.; Nicolucci, A.; Davi, G.; Consoli, A. Decreased in vivo oxidative stress and decreased platelet activation following metformin treatment in newly diagnosed type 2 diabetic subjects. Diabetes Metab. Res. Rev. 2008, 24, 231-237. [CrossRef]

298. Sena, C.M.; Louro, T.; Matafome, P.; Nunes, E.; Monteiro, P.; Seica, R. Antioxidant and vascular effects of gliclazide in type 2 diabetic rats fed high-fat diet. Physiol. Res. 2009, 58, 203-209. [CrossRef]

299. Chen, L.L.; Liao, Y.F.; Zeng, T.S.; Yu, F.; Li, H.Q.; Feng, Y. Effects of metformin plus gliclazide compared with metformin alone on circulating endothelial progenitor cell in type 2 diabetic patients. Endocrine 2010, 38, 266-275. [CrossRef] [PubMed]

300. Xiao-Yun, X.; Zhao-Hui, M.; Ke, C.; Hong-Hui, H.; Yan-Hong, X. Glucagon-like peptide-1 improves proliferation and differentiation of endothelial progenitor cells via upregulating VEGF generation. Med. Sci. Monit. 2011, 17, BR35-BR41. [CrossRef] [PubMed]

301. Goncalves, A.; Leal, E.; Paiva, A.; Teixeira Lemos, E.; Teixeira, F.; Ribeiro, C.F.; Reis, F.; Ambrosio, A.F.; Fernandes, R. Protective effects of the dipeptidyl peptidase IV inhibitor sitagliptin in the blood-retinal barrier in a type 2 diabetes animal model. Diabetes Obes. Metab. 2012, 14, 454-463. [CrossRef]

302. Won, S.; Sayeed, I.; Peterson, B.L.; Wali, B.; Kahn, J.S.; Stein, D.G. Vitamin D prevents hypoxia/reoxygenation-induced blood-brain barrier disruption via vitamin D receptor-mediated NF-kB signaling pathways. PLoS ONE 2015, 10, e0122821. [CrossRef]

303. Kim, D.H.; Meza, C.A.; Clarke, H.; Kim, J.S.; Hickner, R.C. Vitamin D and Endothelial Function. Nutrients 2020, 12, 575. [CrossRef] [PubMed]

304. Cianciolo, G.; La Manna, G.; Della Bella, E.; Cappuccilli, M.L.; Angelini, M.L.; Dormi, A.; Capelli, I.; Laterza, C.; Costa, R.; Alviano, F.; et al. Effect of vitamin D receptor activator therapy on vitamin D receptor and osteocalcin expression in circulating endothelial progenitor cells of hemodialysis patients. Blood Purif. 2013, 35, 187-195. [CrossRef] [PubMed]

305. Hammer, Y.; Soudry, A.; Levi, A.; Talmor-Barkan, Y.; Leshem-Lev, D.; Singer, J.; Kornowski, R.; Lev, E.I. Effect of vitamin D on endothelial progenitor cells function. PLoS ONE 2017, 12, e0178057. [CrossRef] [PubMed]

306. Ackermann, M.; Pabst, A.M.; Houdek, J.P.; Ziebart, T.; Konerding, M.A. Priming with proangiogenic growth factors and endothelial progenitor cells improves revascularization in linear diabetic wounds. Int. J. Mol. Med. 2014, 33, 833-839. [CrossRef]

307. Mees, B.; Recalde, A.; Loinard, C.; Tempel, D.; Godinho, M.; Vilar, J.; van Haperen, R.; Levy, B.; de Crom, R.; Silvestre, J.S. Endothelial nitric oxide synthase overexpression restores the efficiency of bone marrow mononuclear cell-based therapy. Am. J. Pathol. 2011, 178, 55-60. [CrossRef]

308. Essaadi, A.; Nollet, M.; Moyon, A.; Stalin, J.; Simoncini, S.; Balasse, L.; Bertaud, A.; Bachelier, R.; Leroyer, A.S.; Sarlon, G.; et al. Stem cell properties of peripheral blood endothelial progenitors are stimulated by soluble CD146 via miR-21: Potential use in autologous cell therapy. Sci. Rep. 2018, 8, 9387. [CrossRef] [PubMed]

309. Masaki, T. Possible role of endothelin in endothelial regulation of vascular tone. Annu. Rev. Pharmacol. Toxicol. 1995, 35, 235-255. [CrossRef]

310. Johnston, C.I. Franz Volhard Lecture. Renin-angiotensin system: A dual tissue and hormonal system for cardiovascular control. J. Hypertens. Suppl. 1992, 10, S13-S26. [CrossRef]

311. Rossi, G.P.; Sacchetto, A.; Cesari, M.; Pessina, A.C. Interactions between endothelin-1 and the renin-angiotensin-aldosterone system. Cardiovasc. Res. 1999, 43, 300-307. [CrossRef]

312. Bahlmann, F.H.; de Groot, K.; Mueller, O.; Hertel, B.; Haller, H.; Fliser, D. Stimulation of endothelial progenitor cells: A new putative therapeutic effect of angiotensin II receptor antagonists. Hypertension 2005, 45, 526-529. [CrossRef]

313. Steinmetz, M.; Brouwers, C.; Nickenig, G.; Wassmann, S. Synergistic effects of telmisartan and simvastatin on endothelial progenitor cells. J. Cell. Mol. Med. 2010, 14, 1645-1656. [CrossRef]

314. Reinhard, H.; Jacobsen, P.K.; Lajer, M.; Pedersen, N.; Billestrup, N.; Mandrup-Poulsen, T.; Parving, H.H.; Rossing, P. Multifactorial treatment increases endothelial progenitor cells in patients with type 2 diabetes. Diabetologia 2010, 53, 2129-2133. [CrossRef]

315. Jung, C.; Rafnsson, A.; Brismar, K.; Pernow, J. Endothelial progenitor cells in relation to endothelin-1 and endothelin receptor blockade: A randomized, controlled trial. Int. J. Cardiol. 2013, 168, 1017-1022. [CrossRef] 
316. Ociepa, T.; Bartnik, M.; Zielezinska, K.; Prokowska, M.; Urasinska, E.; Urasinski, T. Abnormal correlation of circulating endothelial progenitor cells and endothelin-1 concentration may contribute to the development of arterial hypertension in childhood acute lymphoblastic leukemia survivors. Hypertens. Res. 2016, 39, 530-535. [CrossRef]

317. Zhai, L.; Liu, Y.; Zhao, W.; Chen, Q.; Guo, T.; Wei, W.; Luo, Z.; Huang, Y.; Ma, C.; Huang, F.; et al. Aerobic and resistance training enhances endothelial progenitor cell function via upregulation of caveolin-1 in mice with type 2 diabetes. Stem Cell Res. Ther. 2020, 11, 10. [CrossRef]

318. Sonnenschein, K.; Horvath, T.; Mueller, M.; Markowski, A.; Siegmund, T.; Jacob, C.; Drexler, H.; Landmesser, U. Exercise training improves in vivo endothelial repair capacity of early endothelial progenitor cells in subjects with metabolic syndrome. Eur. J. Cardiovasc. Prev. Rehabil. 2011, 18, 406-414. [CrossRef]

319. Fernandez, J.M.; Rosado-Alvarez, D.; Da Silva Grigoletto, M.E.; Rangel-Zuniga, O.A.; Landaeta-Diaz, L.L.; Caballero-Villarraso, J.; Lopez-Miranda, J.; Perez-Jimenez, F.; Fuentes-Jimenez, F. Moderate-to-high-intensity training and a hypocaloric Mediterranean diet enhance endothelial progenitor cells and fitness in subjects with the metabolic syndrome. Clin. Sci. 2012, 123, 361-373. [CrossRef] [PubMed]

320. Li, L.; Whiteman, M.; Guan, Y.Y.; Neo, K.L.; Cheng, Y.; Lee, S.W.; Zhao, Y.; Baskar, R.; Tan, C.H.; Moore, P.K. Characterization of a novel, water-soluble hydrogen sulfide-releasing molecule (GYY4137): New insights into the biology of hydrogen sulfide. Circulation 2008, 117, 2351-2360. [CrossRef] [PubMed]

321. Liu, Z.; Han, Y.; Li, L.; Lu, H.; Meng, G.; Li, X.; Shirhan, M.; Peh, M.T.; Xie, L.; Zhou, S.; et al. The hydrogen sulfide donor, GYY4137, exhibits anti-atherosclerotic activity in high fat fed apolipoprotein E(-/-) mice. Br. J. Pharmacol. 2013, 169, 1795-1809. [CrossRef]

322. Tomasova, L.; Pavlovicova, M.; Malekova, L.; Misak, A.; Kristek, F.; Grman, M.; Cacanyiova, S.; Tomasek, M.; Tomaskova, Z.; Perry, A.; et al. Effects of AP39, a novel triphenylphosphonium derivatised anethole dithiolethione hydrogen sulfide donor, on rat haemodynamic parameters and chloride and calcium Cav3 and RyR2 channels. Nitric Oxide 2015, 46, 131-144. [CrossRef]

323. Xiong, Y.; Chang, L.L.; Tran, B.; Dai, T.; Zhong, R.; Mao, Y.C.; Zhu, Y.Z. ZYZ-803, a novel hydrogen sulfide-nitric oxide conjugated donor, promotes angiogenesis via cross-talk between STAT3 and CaMKII. Acta Pharmacol. Sin. 2020, 41, 218-228. [CrossRef]

324. Hu, Q.; Ke, X.; Zhang, T.; Chen, Y.; Huang, Q.; Deng, B.; Xie, S.; Wang, J.; Nie, R. Hydrogen sulfide improves vascular repair by promoting endothelial nitric oxide synthase-dependent mobilization of endothelial progenitor cells. J. Hypertens. 2019, 37, 972-984. [CrossRef]

325. DiNicolantonio, J.J.; JH, O.K.; McCarty, M.F. Boosting endogenous production of vasoprotective hydrogen sulfide via supplementation with taurine and N-acetylcysteine: A novel way to promote cardiovascular health. Open Heart 2017, 4, e000600. [CrossRef]

326. Sun, Q.; Wang, B.; Li, Y.; Sun, F.; Li, P.; Xia, W.; Zhou, X.; Li, Q.; Wang, X.; Chen, J.; et al. Taurine Supplementation Lowers Blood Pressure and Improves Vascular Function in Prehypertension: Randomized, Double-Blind, Placebo-Controlled Study. Hypertension 2016, 67, 541-549. [CrossRef]

327. Benavides, G.A.; Squadrito, G.L.; Mills, R.W.; Patel, H.D.; Isbell, T.S.; Patel, R.P.; Darley-Usmar, V.M.; Doeller, J.E.; Kraus, D.W. Hydrogen sulfide mediates the vasoactivity of garlic. Proc. Natl. Acad. Sci. USA 2007, 104, 17977-17982. [CrossRef]

328. Polhemus, D.; Kondo, K.; Bhushan, S.; Bir, S.C.; Kevil, C.G.; Murohara, T.; Lefer, D.J.; Calvert, J.W. Hydrogen sulfide attenuates cardiac dysfunction after heart failure via induction of angiogenesis. Circ. Heart Fail. 2013, 6, 1077-1086. [CrossRef]

329. Sharma, D.K.; Manral, A.; Saini, V.; Singh, A.; Srinivasan, B.P.; Tiwari, M. Novel diallyldisulfide analogs ameliorate cardiovascular remodeling in rats with L-NAME-induced hypertension. Eur. J. Pharmacol. 2012, 691, 198-208. [CrossRef] [PubMed]

330. Basile, D.P.; Yoder, M.C. Circulating and tissue resident endothelial progenitor cells. J. Cell. Physiol. 2014, 229, 10-16. [CrossRef]

331. Yoder, M.C. Endothelial progenitor cell: A blood cell by many other names may serve similar functions. J. Mol. Med. 2013, 91, 285-295. [CrossRef] [PubMed]

332. Chong, M.S.; Ng, W.K.; Chan, J.K. Concise Review: Endothelial Progenitor Cells in Regenerative Medicine: Applications and Challenges. Stem Cells Transl. Med. 2016, 5, 530-538. [CrossRef]

333. Wang, X.X.; Zhang, F.R.; Shang, Y.P.; Zhu, J.H.; Xie, X.D.; Tao, Q.M.; Zhu, J.H.; Chen, J.Z. Transplantation of autologous endothelial progenitor cells may be beneficial in patients with idiopathic pulmonary arterial hypertension: A pilot randomized controlled trial. J. Am. Coll. Cardiol. 2007, 49, 1566-1571. [CrossRef] [PubMed] 